Article

\title{
Two Achilles' Heels of the Ebolavirus Glycoprotein?
}

\author{
Wei Li(i)* \\ 1 Institute of Special Environment Medicine, Nantong University, No. 9, Seyuan Road, Nantong City, Jiangsu \\ Province, P. R. China \\ * Correspondence: wli148@aucklanduni.ac.nz
}

Received: date; Accepted: date; Published: date

\begin{abstract}
Ebolavirus has a membrane envelope decorated by trimers of a glycoprotein (GP), which is responsible for host cell attachment and membrane fusion. Therefore, GP is a primary target for antiviral drugs development. Here, this article reports the first, to my knowledge, set of structural analysis of all Ebolavirus GP structures as of March 10, 2020, and also a brief update of the structurally identified electrostatic features of the Ebolavirus GP structures in both apo (unliganded) state and also in bound states with a series of small compounds, including a variety of approved drugs. With this comprehensive set of structural analysis, this article puts forward a hypothesis of two Achilles' heels of Ebolavirus GP structure, where the formation of two interfacial salt bridges, instead of destabilizing the prefusion conformation of Ebolavirus GP, constitutes a positive contribution towards the structural rigidification of the prefusion conformation of the Ebolavirus GP structure, thereby acting against GP-mediated Ebolavirus cell entry and/or preventing fusion between the viral and endosome membranes.
\end{abstract}

Keywords: Ebolavirus glycoprotein; Electrostatic interaction; Salt bridging network; Two Achilles' heels

\section{Introduction}

Ebolavirus is a rare but deadly virus that causes fever, body aches, and diarrhoea, and sometimes bleeding inside and outside the body [1-13]. Structurally, Ebolavirus has a membrane envelope decorated by trimers of a glycoprotein, i.e., GP, which is cleaved by furin to form GP1 and GP2 subunits [14-49]. Functionally, GP is responsible for host cell attachment, endosomal entry and membrane fusion, making it a critical target for the development of antiviral drugs [17,50,50-57].

\section{Motivation}

Experimental studies around the Ebolavirus disease, both fundamental and clinical, have been reported extensively in recent years [58-114]. For instance, a set of Ebolavirus GP experimental structures were reported [14-16,115-117], including both apo (unliganded) structure of Ebolavirus GP, and also high-resolution complex structures of GP with a series of directly interacting compounds (including a variety of approved drugs) and also its neutralizing antibodies (Tables 1 and 2).

While the recent structural studies [14-16,115-117] painted an overall experimental picture of the Ebolavirus GP molecule, allowing conformational changes induced by antibody and receptor binding to be deciphered, in-depth structural and functional details, including its mechanism of inhibition, i.e., action mode of mediating virus cell entry [118-125] and possible conformational dynamics associated with it, are still to be investigated further, both experimentally and computationally [126,127]. As previously reported, the protein-drug interactions with both GP1 and GP2 are predominately hydrophobic [14-16,115-117], thus, from a structural point of view, this article aims to extract all electrostatic features embedded in all experimentally determined Ebolavirus GP structures currently available as of March 10, 2020. 


\section{Materials and Methods}

As of March 10, 2020, the Protein Data Bank (PDB) [128] hosts 36 Ebolavirus glycoprotein structures, as listed in Table 1 below,

\begin{tabular}{|c|c|c|}
\hline No. & PDB ID & Structure Title \\
\hline 1 & $1 \mathrm{EBO}$ & $\begin{array}{l}\text { Crystal structure of the Ebolavirus membrane-fusion subunit, gp2, from the envelope } \\
\text { glycoprotein ectodomain }\end{array}$ \\
\hline 2 & $2 \mathrm{EBO}$ & Core structure of gp2 from Ebolavirus \\
\hline 3 & 2QHR & $\begin{array}{l}\text { Crystal structure of the } 13 \mathrm{f} 6-1-2 \text { fab fragment bound to its Ebolavirus glycoprotein } \\
\text { peptide epitope. }\end{array}$ \\
\hline 4 & 2RLJ & NMR structure of Ebola fusion peptide in SDS micelles at pH 7 \\
\hline 5 & $2 \mathrm{Y} 6 \mathrm{~S}$ & $\begin{array}{l}\text { Structure of an Ebolavirus-protective antibody in complex with its mucin-domain linear } \\
\text { epitope }\end{array}$ \\
\hline 6 & 3CSY & $\begin{array}{l}\text { Crystal structure of the trimeric prefusion Ebolavirus glycoprotein in complex with a } \\
\text { neutralizing antibody from a human survivor }\end{array}$ \\
\hline 7 & 3VE0 & Crystal structure of sudan Ebolavirus glycoprotein (strain boniface) bound to $16 \mathrm{f} 6$ \\
\hline 8 & 5F1B & $\begin{array}{l}\text { Structural basis of Ebolavirus entry: viral glycoprotein bound to its endosomal receptor } \\
\text { Niemann-Pick C1 }\end{array}$ \\
\hline 9 & $5 \mathrm{FHC}$ & $\begin{array}{l}\text { Crystal Structure of Protective Human Antibodies } 100 \text { and } 114 \text { in Complex with Ebola } \\
\text { Virus Fusion Glycoprotein (GP) }\end{array}$ \\
\hline 10 & $5 \mathrm{HJ} 3$ & Crystal structure of host-primed Ebolavirus GP, GPcl \\
\hline 11 & $5 \mathrm{JNX}$ & $\begin{array}{l}\text { The } 6.6 \AA \text { Cryo-EM structure of the full-length human NPC1 in complex with the } \\
\text { cleaved glycoprotein of Ebolavirus }\end{array}$ \\
\hline 12 & 5JQ3 & Crystal structure of Ebola glycoprotein \\
\hline 13 & 5JQ7 & Crystal structure of Ebola glycoprotein in complex with toremifene \\
\hline 14 & 5JQB & Crystal structure of Ebola glycoprotein in complex with ibuprofen \\
\hline 15 & 5KEL & EBOV GP in complex with variable Fab domains of IgGs c2G4 and c13C6 \\
\hline 16 & 5KEM & EBOV sGP in complex with variable Fab domains of IgGs c13C6 and BDBV91 \\
\hline 17 & $5 \mathrm{KEN}$ & EBOV GP in complex with variable Fab domains of IgGs c4G7 and c13C6 \\
\hline 18 & $5 \mathrm{~T} 42$ & $\begin{array}{l}\text { Structure of the Ebolavirus envelope protein MPER/TM domain and its interaction } \\
\text { with the fusion loop explains their fusion activity }\end{array}$ \\
\hline 19 & 6DZL & $\begin{array}{l}\text { Ebolavirus Makona variant GP (mucin-deleted) in complex with pan-ebolavirus human } \\
\text { antibody ADI-15878 Fab }\end{array}$ \\
\hline 20 & 6EA7 & Structure of EBOV GPcl in complex with the pan-ebolavirus mAb ADI-15878 \\
\hline 21 & $6 \mathrm{~F} 5 \mathrm{U}$ & Crystal structure of Ebolavirus glycoprotein in complex with bepridil \\
\hline 22 & 6F6I & Crystal structure of Ebolavirus glycoprotein in complex with paroxetine \\
\hline 23 & $6 \mathrm{~F} 6 \mathrm{~N}$ & Crystal structure of Ebolavirus glycoprotein in complex with sertraline \\
\hline 24 & $6 \mathrm{~F} 6 \mathrm{~S}$ & Crystal structure of Ebolavirus glycoprotein in complex with benztropine \\
\hline 25 & 6G95 & Crystal structure of Ebolavirus glycoprotein in complex with thioridazine \\
\hline 26 & 6G9B & Crystal structure of Ebolavirus glycoprotein in complex with imipramine \\
\hline 27 & 6G9I & Crystal structure of Ebolavirus glycoprotein in complex with clomipramine \\
\hline 28 & $6 \mathrm{HRO}$ & Crystal structure of Ebolavirus glycoprotein in complex with inhibitor 118a \\
\hline 29 & $6 \mathrm{HS} 4$ & Crystal structure of Ebolavirus glycoprotein in complex with inhibitor 118 \\
\hline 30 & 6MAM & Cleaved Ebola gp in complex with a broadly neutralizing human antibody, adi-15946 \\
\hline 31 & 6NAE & Crystal Structure of Ebola zaire GP protein with bound ARN0074898 \\
\hline 32 & 6QD7 & EM structure of a EBOV-GP bound to 3T0331 neutralizing antibody \\
\hline 33 & 6QD8 & EM structure of a EBOV-GP bound to 4M0368 neutralizing antibody \\
\hline 34 & $6 \mathrm{~S} 8 \mathrm{D}$ & Structure of ZEBOV GP in complex with 1T0227 antibody \\
\hline 35 & $6 \mathrm{~S} 8 \mathrm{I}$ & Structure of ZEBOV GP in complex with 3T0265 antibody \\
\hline 36 & 6S8J & Structure of ZEBOV GP in complex with 5T0180 antibody \\
\hline
\end{tabular}

Table 1. Experimentally determined Ebolavirus GP structures inside Protein Data Bank (PDB [128]) as of March 10, 2020 with a Text Search for: ebola glycoprotein and Molecule: Envelope glycoprotein. 
Among the 36 in Table 1, 12 were experimentally determined structures of Ebolavirus glycoprotein in complex with a set of compounds (Table 2), including a variety of approved drugs [14-16,115-117].

\begin{tabular}{|l|c|l|}
\hline No. & PDB ID & Structure Title \\
\hline 12 & 5JQ3 & Crystal structure of Ebola glycoprotein \\
\hline 13 & 5JQ7 & Crystal structure of Ebola glycoprotein in complex with toremifene \\
\hline 14 & 5JQB & Crystal structure of Ebola glycoprotein in complex with ibuprofen \\
\hline 21 & $6 \mathrm{~F} 5 \mathrm{U}$ & Crystal structure of Ebolavirus glycoprotein in complex with bepridil \\
\hline 22 & $6 \mathrm{~F} 6 \mathrm{I}$ & Crystal structure of Ebolavirus glycoprotein in complex with paroxetine \\
\hline 23 & $6 \mathrm{~F} 6 \mathrm{~N}$ & Crystal structure of Ebolavirus glycoprotein in complex with sertraline \\
\hline 24 & $6 \mathrm{~F} 6 \mathrm{~S}$ & Crystal structure of Ebolavirus glycoprotein in complex with benztropine \\
\hline 25 & $6 \mathrm{G} 95$ & Crystal structure of Ebolavirus glycoprotein in complex with thioridazine \\
\hline 26 & $6 \mathrm{G} 9 \mathrm{~B}$ & Crystal structure of Ebolavirus glycoprotein in complex with imipramine \\
\hline 27 & $6 \mathrm{G} 9 \mathrm{I}$ & Crystal structure of Ebolavirus glycoprotein in complex with clomipramine \\
\hline 28 & $6 \mathrm{HRO}$ & Crystal structure of Ebolavirus glycoprotein in complex with inhibitor 118a \\
\hline 29 & $6 \mathrm{HS} 4$ & Crystal structure of Ebolavirus glycoprotein in complex with inhibitor 118 \\
\hline
\end{tabular}

Table 2. Experimentally determined structures of Ebolavirus GP in complex with a series of small molecules as of March 10, 2020. In this table, the numbers in the first column are taken directly from Table 1.

After all 36 structures (Table 1) were accessed and downloaded directly from the PDB website [128], a comprehensive set of electrostatic interaction (including salt bridging and hydrogen bonding) analysis was subsequently carried out as described in [129] previously.

\section{Results}

\subsection{Electrostatic features embedded inside Ebolavirus glycoprotein structures: a brief update}

With the electrostatic analysis as described previously in [129], this article puts forward a comprehensive set of electrostatic interaction features for the 36 Ebolavirus glycoprotein structures as of March 10, 2020, all included as a large set of separate tables in the supplementary file supplementary.pdf, including specifically:

1. all salt bridges formed within the 36 Ebolavirus glycoprotein structures as of March 10, 2020.

2. all interfacial salt bridges formed within the 36 Ebolavirus glycoprotein structures as of March $10,2020$.

3. all salt bridges formed within the 36 Ebolavirus glycoprotein structures as of March 10, 2020 PDB ID-specifically.

4. all interfacial salt bridges formed within the 36 Ebolavirus glycoprotein structures as of March 10, 2020 PDB ID-specifically.

5. all main and side chains hydrogen bonds formed within the 36 Ebolavirus glycoprotein structures as of March 10, 2020.

6. all side chain hydrogen bonds formed within the 36 Ebolavirus glycoprotein structures as of March 10, 2020.

7. all main and side chains hydrogen bonds formed within the 36 Ebolavirus glycoprotein structures as of March 10, 2020 PDB ID-specifically.

8. all side chain hydrogen bonds formed within the 36 Ebolavirus glycoprotein structures as of March 10, 2020 PDB ID-specifically. 


\subsection{An electrostatic investigation into the complex structures of Ebolavirus GP bound to small molecules}

This article aims to delve into the experimentally determined complex structures of Ebolavirus GP bound to small molecules [14-16,115-117]. Thus, from Table 1, all complex structures of Ebolavirus GP bound to small molecules were singled out and listed in Tables 2 and 3, respectively, where the second and the third columns of Table 3 are taken directly from Table 2, as listed below.

\begin{tabular}{|c|c|c|}
\hline Salt bridging analysis & PDB ID & Structure Title in Abstract \\
\hline Initial template structure for interfacial differential salt bridging analysis & 5JQ3 & GP \\
\hline B_LYS_510-A_GLU_292,B_LYS_510-A_GLU_292,B_LYS_588-A_ASP_47,B_LYS_588-A_ASP_47 & 5JQB & GP + ibuprofen \\
\hline B_LYS_510-A_GLU_292 & 6F6I & GP + paroxetine \\
\hline B_LYS_510-A_GLU_292,B_LYS_588-A_ASP_47,B_LYS_588-A_ASP_47 & $6 \mathrm{~F} 6 \mathrm{~N}$ & GP + sertraline \\
\hline B_LYS_510-A_GLU_292,B_LYS_510-A_GLU_292, B_LYS_588-A_ASP_47,B_LYS_588-A_ASP_47 & $6 \mathrm{~F} 6 \mathrm{~S}$ & GP + benztropine \\
\hline \multirow[t]{2}{*}{ B_LYS_510-A_GLU_292,B_LYS_588-A_ASP_47,B_LYS_588-A_ASP_47 } & 6G9B & GP + imipramine \\
\hline & 6G9I & GP + clomipramine \\
\hline B_LYS_510-A_GLU_292,B_LYS_588-A_ASP_47,B_LYS_588-A_ASP_47 & $6 \mathrm{HRO}$ & GP + inhibitor 118a \\
\hline B_LYS_588-A_ASP_47,B_LYS_588-A_ASP_47 & $6 \mathrm{HS} 4$ & GP + inhibitor 118 \\
\hline
\end{tabular}

Table 3. A differential analysis of the interfacial salt bridging analysis of the experimentally determined structures of Ebolavirus GP in complex with small molecules as of March 10, 2020. In this table, the second and the third columns are taken directly from Table 1, while the first column represents the differential salt bridging analysis of the 11 structures against the apo unliganded crystal structure of GP (PDB ID: 5JQ3, the initial template structure for the differential salt bridging analysis). Moreover, the B_LYS_588-A_ASP_47 represents the interfacial salt bridge formed due to the presence of the small molecules compared with the apo-state Ebolavirus GP structure, while the B_LYS_510-A_GLU_292 represents the interfacial salt bridge formed due to the presence of the small molecules compared with the apo-state Ebolavirus GP structure, too. Furthermore in this table, the residue naming scheme is Chain ID_residue name_residue number, the residue pair naming scheme is Chain ID_residue name_residue number-Chain ID_residue name_residue number.

\begin{tabular}{|l|}
\hline A differential salt bridging analysis between 5JQ3 and 5JQ7 (Table 3) \\
\hline Common salt bridges between 5JQ3 and 5JQ7 \\
\hline A_HIS_39-A_ASP_55 \\
\hline A_HIS_39-A_ASP_55 \\
\hline A_ARG_85-A_GLU_178 \\
\hline A_ARG_85-A_GLU_178 \\
\hline A_LYS_114-A_GLU_120 \\
\hline A_LYS_114-A_GLU_120 \\
\hline A_ARG_130-A_ASP_163 \\
\hline A_HIS_154-A_GLU_178 \\
\hline A_ARG_164-A_ASP_163 \\
\hline A_ARG_164-A_ASP_163 \\
\hline A_ARG_266-A_ASP_237 \\
\hline B_HIS_516-B_GLU_545 \\
\hline B_ARG_559-A_GLU_103 \\
\hline B_ARG_559-A_GLU_103 \\
\hline B_ARG_559-A_GLU_103 \\
\hline B_ARG_559-A_GLU_103 \\
\hline Structurally identified 5JQ3-only salt bridges \\
\hline No 5JQ3-only salt bridge was structurally identified here \\
\hline Structurally identified 5JQ7-only salt bridges \\
\hline A_ARG_247-A_GLU_245 \\
\hline
\end{tabular}




\begin{tabular}{|l|}
\hline A_ARG_247-A_GLU_245 \\
\hline B_LYS_510-A_GLU_292 \\
\hline B_HIS_613-B_ASP_614 \\
\hline A differential salt bridging analysis between 5JQ3 and 5JQB (Table 3) \\
\hline Common salt bridges between 5JQ3 and 5JQB \\
\hline A_ARG_85-A_GLU_178 \\
\hline A_ARG_85-A_GLU_178 \\
\hline A_LYS_114-A_GLU_120 \\
\hline A_LYS_114-A_GLU_120 \\
\hline A_ARG_130-A_ASP_163 \\
\hline A_HIS_154-A_GLU_178 \\
\hline A_ARG_164-A_ASP_163 \\
\hline A_ARG_164-A_ASP_163 \\
\hline A_ARG_266-A_ASP_237 \\
\hline B_HIS_516-B_GLU_545 \\
\hline B_ARG_559-A_GLU_103 \\
\hline B_ARG_559-A_GLU_103 \\
\hline B_ARG_559-A_GLU_103 \\
\hline B_ARG_559-A_GLU_103 \\
\hline Structurally identified 5JQ3-only salt bridges \\
\hline A_HIS_39-A_ASP_55 \\
\hline A_HIS_39-A_ASP_55 \\
\hline Structurally identified 5JQB-only salt bridges \\
\hline A_ARG_247-A_GLU_245 \\
\hline B_LYS_510-A_GLU_292 \\
\hline B_LYS_510-A_GLU_292 \\
\hline B_LYS_588-A_ASP_47 \\
\hline B_LYS_588-A_ASP_47 \\
\hline B_LYS_617-B_ASP_614 \\
\hline A differential salt bridging analysis between 5JQ3 and 6F5U (Table 3) \\
\hline Common salt bridges between 5JQ3 and 6F5U \\
\hline A_HIS_39-A_ASP_55 \\
\hline A_HIS_39-A_ASP_55 \\
\hline A_ARG_85-A_GLU_178 \\
\hline A_ARG_85-A_GLU_178 \\
\hline A_LYS_114-A_GLU_120 \\
\hline A_LYS_114-A_GLU_120 \\
\hline A_ARG_130-A_ASP_163 \\
\hline A_HIS_154-A_GLU_178 \\
\hline A_ARG_164-A_ASP_163 \\
\hline A_ARG_164-A_ASP_163 \\
\hline A_ARG_266-A_ASP_237 \\
\hline B_HIS_516-B_GLU_545 \\
\hline B_ARG_559-A_GLU_103 \\
\hline B_ARG_559-A_GLU_103 \\
\hline B_ARG_559-A_GLU_103 \\
\hline B_ARG_559-A_GLU_103 \\
\hline Structurally identified 5JQ3-only salt bridges \\
\hline
\end{tabular}




\begin{tabular}{|l|}
\hline No 5JQ3-only salt bridge was structurally identified here \\
\hline Structurally identified 6F5U-only salt bridges \\
\hline A_ARG_247-A_GLU_245 \\
\hline B_LYS_510-A_GLU_292 \\
\hline A differential salt bridging analysis between 5JQ3 and 6F6I (Table 3) \\
\hline Common salt bridges between 5JQ3 and 6F6I \\
\hline A_ARG_85-A_GLU_178 \\
\hline A_ARG_85-A_GLU_178 \\
\hline A_LYS_114-A_GLU_120 \\
\hline A_LYS_114-A_GLU_120 \\
\hline A_ARG_130-A_ASP_163 \\
\hline A_HIS_154-A_GLU_178 \\
\hline A_ARG_164-A_ASP_163 \\
\hline A_ARG_164-A_ASP_163 \\
\hline A_ARG_266-A_ASP_237 \\
\hline B_HIS_516-B_GLU_545 \\
\hline B_ARG_559-A_GLU_103 \\
\hline B_ARG_559-A_GLU_103 \\
\hline B_ARG_559-A_GLU_103 \\
\hline B_ARG_559-A_GLU_103 \\
\hline Structurally identified 5JQ3-only salt bridges \\
\hline A_HIS_39-A_ASP_55 \\
\hline A_HIS_39-A_ASP_55 \\
\hline Structurally identified 6F6I-only salt bridges \\
\hline A_LYS_140-A_GLU_112 \\
\hline A_ARG_247-A_GLU_245 \\
\hline B_LYS_510-A_GLU_292 \\
\hline B_HIS_628-B_ASP_629 \\
\hline B_HIS_628-B_ASP_629 \\
\hline A differential salt bridging analysis between 5JQ3 and 6F6N (Table 3) \\
\hline Common salt bridges between 5JQ3 and 6F6N \\
\hline A_ARG_85-A_GLU_178 \\
\hline A_ARG_85-A_GLU_178 \\
\hline A_LYS_114-A_GLU_120 \\
\hline A_LYS_114-A_GLU_120 \\
\hline A_ARG_130-A_ASP_163 \\
\hline A_HIS_154-A_GLU_178 \\
\hline A_ARG_164-A_ASP_163 \\
\hline A_ARG_164-A_ASP_163 \\
\hline A_ARG_266-A_ASP_237 \\
\hline B_HIS_516-B_GLU_545 \\
\hline B_ARG_559-A_GLU_103 \\
\hline B_ARG_559-A_GLU_103 \\
\hline B_ARG_559-A_GLU_103 \\
\hline B_ARG_559-A_GLU_103 \\
\hline Structurally identified 5JQ3-only salt bridges \\
\hline A_HIS_39-A_ASP_55 \\
\hline A_HIS_39-A_ASP_55 \\
\hline
\end{tabular}




\begin{tabular}{|l|}
\hline Structurally identified 6F6N-only salt bridges \\
\hline A_LYS_50-A_ASP_49 \\
\hline A_LYS_50-A_ASP_49 \\
\hline A_ARG_247-A_GLU_245 \\
\hline A_LYS_276-A_GLU_245 \\
\hline B_LYS_510-A_GLU_292 \\
\hline B_LYS_588-A_ASP_47 \\
\hline B_LYS_588-A_ASP_47 \\
\hline A differential salt bridging analysis between 5JQ3 and 6F6S (Table 3) \\
\hline Common salt bridges between 5JQ3 and 6F6S \\
\hline A_ARG_85-A_GLU_178 \\
\hline A_ARG_85-A_GLU_178 \\
\hline A_LYS_114-A_GLU_120 \\
\hline A_LYS_114-A_GLU_120 \\
\hline A_ARG_130-A_ASP_163 \\
\hline A_HIS_154-A_GLU_178 \\
\hline A_ARG_164-A_ASP_163 \\
\hline A_ARG_164-A_ASP_163 \\
\hline B_HIS_516-B_GLU_545 \\
\hline B_ARG_559-A_GLU_103 \\
\hline B_ARG_559-A_GLU_103 \\
\hline B_ARG_559-A_GLU_103 \\
\hline B_ARG_559-A_GLU_103 \\
\hline Structurally identified 5JQ3-only salt bridges \\
\hline A_HIS_39-A_ASP_55 \\
\hline A_HIS_39-A_ASP_55 \\
\hline A_ARG_266-A_ASP_237 \\
\hline Structurally identified 6F6S-only salt bridges \\
\hline B_LYS_510-A_GLU_292 \\
\hline B_LYS_510-A_GLU_292 \\
\hline B_LYS_588-A_ASP_47 \\
\hline B_LYS_588-A_ASP_47 \\
\hline B_LYS_617-B_ASP_614 \\
\hline A differential salt bridging analysis between 5JQ3 and 6G95 (Table 3) \\
\hline Common saltbridges between 5JQ3 and 6G95 \\
\hline A_HIS_39-A_ASP_55 \\
\hline A_HIS_39-A_ASP_55 \\
\hline A_ARG_85-A_GLU_178 \\
\hline A_ARG_85-A_GLU_178 \\
\hline A_LYS_114-A_GLU_120 \\
\hline A_LYS_114-A_GLU_120 \\
\hline A_ARG_130-A_ASP_163 \\
\hline A_HIS_154-A_GLU_178 \\
\hline A_ARG_164-A_ASP_163 \\
\hline A_ARG_164-A_ASP_163 \\
\hline A_ARG_266-A_ASP_237 \\
\hline B_HIS_516-B_GLU_545 \\
\hline B_ARG_559-A_GLU_103 \\
\hline
\end{tabular}




\begin{tabular}{|l|}
\hline B_ARG_559-A_GLU_103 \\
\hline B_ARG_559-A_GLU_103 \\
\hline B_ARG_559-A_GLU_103 \\
\hline Structurally identified 5JQ3-only salt bridges \\
\hline No 5JQ3-only salt bridge was structurally identified here \\
\hline Structurally identified 6G95-only salt bridges \\
\hline A_LYS_140-A_GLU_112 \\
\hline A differential salt bridging analysis between 5JQ3 and 6G9B (Table 3) \\
\hline Common salt bridges between 5JQ3 and 6G9B \\
\hline A_ARG_85-A_GLU_178 \\
\hline A_ARG_85-A_GLU_178 \\
\hline A_LYS_114-A_GLU_120 \\
\hline A_LYS_114-A_GLU_120 \\
\hline A_ARG_130-A_ASP_163 \\
\hline A_HIS_154-A_GLU_178 \\
\hline A_ARG_164-A_ASP_163 \\
\hline A_ARG_164-A_ASP_163 \\
\hline A_ARG_266-A_ASP_237 \\
\hline B_HIS_516-B_GLU_545 \\
\hline B_ARG_559-A_GLU_103 \\
\hline B_ARG_559-A_GLU_103 \\
\hline B_ARG_559-A_GLU_103 \\
\hline B_ARG_559-A_GLU_103 \\
\hline Structurally identified 5JQ3-only salt bridges \\
\hline A_HIS_39-A_ASP_55 \\
\hline A_HIS_39-A_ASP_55 \\
\hline Structurally identified 6G9B-only salt bridges \\
\hline A_LYS_140-A_GLU_112 \\
\hline A_ARG_172-A_GLU_120 \\
\hline A_ARG_247-A_GLU_245 \\
\hline B_LYS_510-A_GLU_292 \\
\hline B_LYS_588-A_ASP_47 \\
\hline B_LYS_588-A_ASP_47 \\
\hline B_LYS_617-B_ASP_614 \\
\hline B_HIS_628-B_ASP_629 \\
\hline B_HIS_628-B_ASP_629 \\
\hline A differential salt bridging analysis between 5JQ3 and 6G9I (Table 3) \\
\hline Common salt bridges between 5JQ3 and 6G9I \\
\hline A_HIS_39-A_ASP_55 \\
\hline A_HIS_39-A_ASP_55 \\
\hline A_ARG_85-A_GLU_178 \\
\hline A_ARG_85-A_GLU_178 \\
\hline A_LYS_114-A_GLU_120 \\
\hline A_LYS_114-A_GLU_120 \\
\hline A_ARG_130-A_ASP_163 \\
\hline A_HIS_154-A_GLU_178 \\
\hline A_ARG_164-A_ASP_163 \\
\hline A_ARG_164-A_ASP_163 \\
\hline
\end{tabular}




\begin{tabular}{|l|}
\hline A_ARG_266-A_ASP_237 \\
\hline B_HIS_516-B_GLU_545 \\
\hline B_ARG_559-A_GLU_103 \\
\hline B_ARG_559-A_GLU_103 \\
\hline B_ARG_559-A_GLU_103 \\
\hline B_ARG_559-A_GLU_103 \\
\hline Structurally identified 5JQ3-only salt bridges \\
\hline No 5JQ3-only salt bridge was structurally identified here \\
\hline Structurally identified 6G9I-only salt bridges \\
\hline B_LYS_622-B_ASP_621 \\
\hline B_LYS_622-B_ASP_621 \\
\hline A differential salt bridging analysis between 5JQ3 and 6HRO (Table 3) \\
\hline Common salt bridges between 5JQ3 and 6HRO \\
\hline A_ARG_85-A_GLU_178 \\
\hline A_ARG_85-A_GLU_178 \\
\hline A_LYS_114-A_GLU_120 \\
\hline A_LYS_114-A_GLU_120 \\
\hline A_ARG_130-A_ASP_163 \\
\hline A_HIS_154-A_GLU_178 \\
\hline A_ARG_164-A_ASP_163 \\
\hline A_ARG_164-A_ASP_163 \\
\hline A_ARG_266-A_ASP_237 \\
\hline B_HIS_516-B_GLU_545 \\
\hline B_ARG_559-A_GLU_103 \\
\hline B_ARG_559-A_GLU_103 \\
\hline B_ARG_559-A_GLU_103 \\
\hline B_ARG_559-A_GLU_103 \\
\hline Structurally identified 5JQ3-only salt bridges \\
\hline A_HIS_39-A_ASP_55 \\
\hline A_HIS_39-A_ASP_55 \\
\hline Structurally identified 6HRO-only salt bridges \\
\hline B_LYS_510-A_GLU_292 \\
\hline B_LYS_588-A_ASP_47 \\
\hline B_LYS_588-A_ASP_47 \\
\hline A differential salt bridging analysis between 5JQ3 and 6HS4 (Table 3) \\
\hline Common salt bridges between 5JQ3 and 6HS4 \\
\hline A_HIS_39-A_ASP_55 \\
\hline A_HIS_39-A_ASP_55 \\
\hline A_ARG_85-A_GLU_178 \\
\hline A_ARG_85-A_GLU_178 \\
\hline A_LYS_114-A_GLU_120 \\
\hline A_LYS_114-A_GLU_120 \\
\hline A_ARG_130-A_ASP_163 \\
\hline A_HIS_154-A_GLU_178 \\
\hline A_ARG_164-A_ASP_163 \\
\hline A_ARG_164-A_ASP_163 \\
\hline A_ARG_266-A_ASP_237 \\
\hline B_HIS_516-B_GLU_545 \\
\hline
\end{tabular}




\begin{tabular}{|l|}
\hline B_ARG_559-A_GLU_103 \\
\hline B_ARG_559-A_GLU_103 \\
\hline B_ARG_559-A_GLU_103 \\
\hline B_ARG_559-A_GLU_103 \\
\hline Structurally identified 5JQ3-only salt bridges \\
\hline No 5JQ3-only salt bridge was structurally identified here \\
\hline Structurally identified 6HS4-only salt bridges \\
\hline B_LYS_588-A_ASP_47 \\
\hline B_LYS_588-A_ASP_47 \\
\hline
\end{tabular}

Table 4. PDBID-specific comparison of structurally identified salt bridging networks of Ebolavirus GP in complex with small molecules (Table 3). In this table, the texts in black represent the structurally identified salt bridges that exist in both apo- and bound-state of the Ebolavirus GP, the texts in green represent the structurally identified salt bridges only in apo-state Ebolavirus GP, while the texts in red represent the structurally identified salt bridges only in the 11 bound-state Ebolavirus GPs, respectively. In addition, in this table, the residue naming scheme is Chain ID_residue name_residue number, the residue pair naming scheme is Chain ID_residue name_residue number-Chain ID_residue name_residue number.

\subsection{A hypothesis of two Achilles' heels of the Ebolavirus glycoprotein}

This article aims to delve into the experimentally determined complex structures of Ebolavirus GP bound to small molecules [14-16,115-117]. Instead of focusing on the common structurally identified salt bridges that exist in both apo- and bound-state of the Ebolavirus GP (Table 4 and Figure 1), this article focused on the structurally identified salt bridges, which are absent in the apo unliganded structure of Ebolavirus GP, but which are present in the 11 bound-state of structure of Ebolavirus GPs (Tables 2 and 3 ).

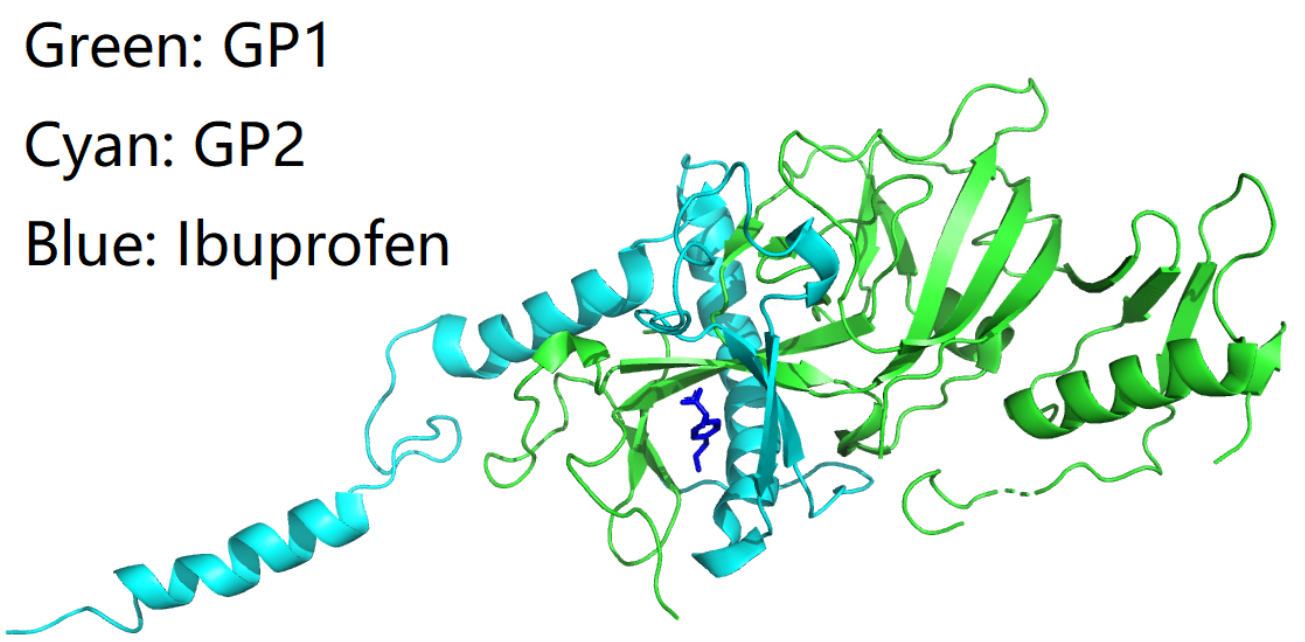

Figure 1. An overall structure of the Ebolavirus glycoprotein in complex with Ibuprofen. In this figure, the Ebolavirus GP is shown as green (chain A: ENVELOPE GLYCOPROTEIN 1) and cyan (chain B: ENVELOPE GLYCOPROTEIN 2) cartoon, while ibuprofen Tables 3 and 4 is shown as dark blue sticks. This figure is prepared using PyMol [130] with 5JQB.pdb (Table 1) as an input. 
As reported previously [14-16,115-117], binding of the small molecules destabilizes the Ebolavirus GP, such as the cases for the anticancer drug toremifene and the painkiller ibuprofen, which bind in the same large cavity on the glycoprotein [14-16,115-117]. Furthermore, crystal structures show that the position of binding and the mode of interaction within the pocket vary significantly between these compounds, which is in agreement with the protein-inhibitor interactions as well as with the antiviral activities determined by virus cell entry assays [14-16,115-117]. While it is likely that this difference stems from the various chemical structures of these small compounds, it is also likely that there are common features in the way these small compounds cause structural perturbations/disturbances to Ebolavirus GP, as evidenced by the structural electrostatic analysis listed in Tables 3 and 4, and illustrated below in Figures 2, 3, 4, 5, 6 and 7, respectively.

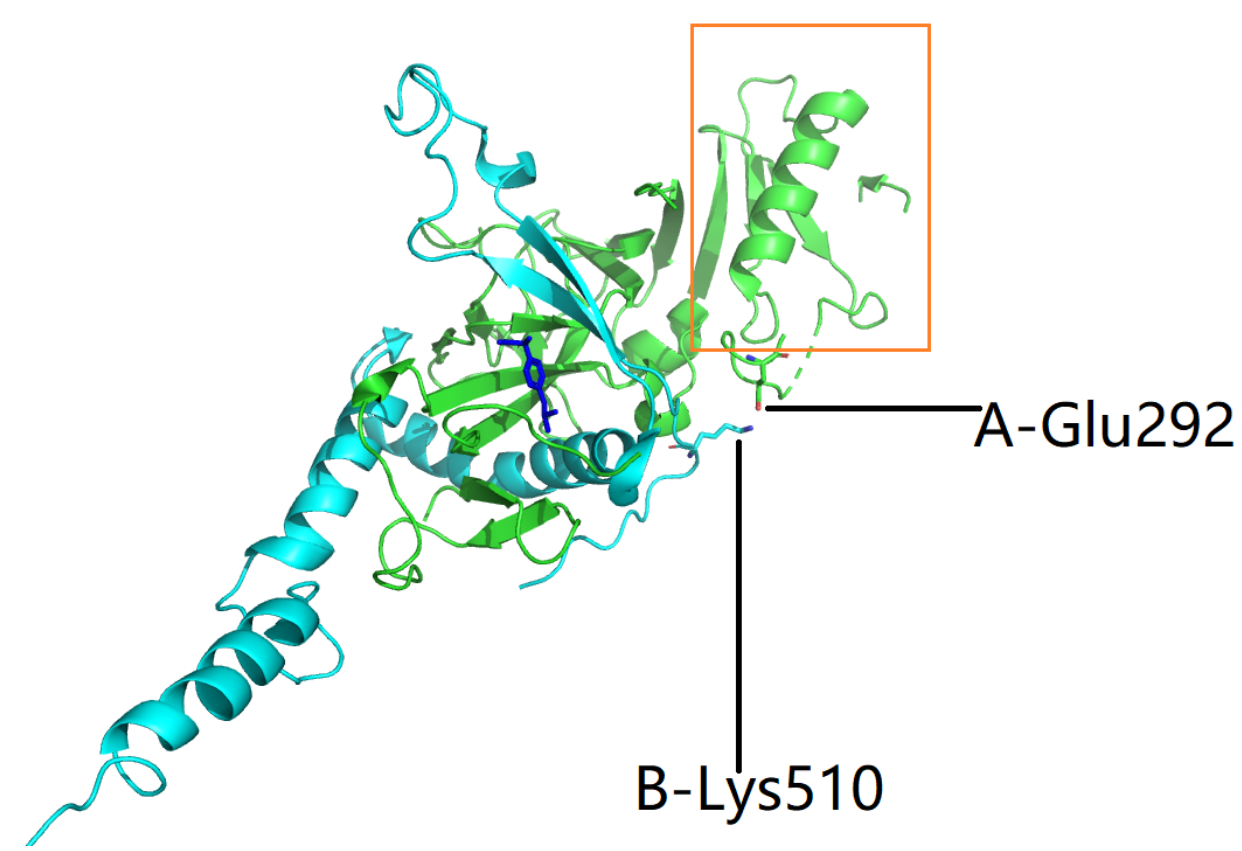

Figure 2. A hypothesis of two Achilles' heels of the Ebolavirus glycoprotein. In this figure, the first hypothesized Achilles' heel is shown as the two structurally identified interfacial salt bridges between B_LYS_510 and A_GLU_292 (Table 3), which helps restrain the inter-chain conformational flexibility of Ebolavirus GP, and also contributes to local inter-chain structural rigidification [131] of Ebolavirus GP, as shown approximately in the region inside the box in orange. This figure is prepared using PyMol [130] with 5JQB.pdb (Table 1) as an input with other details the same as that described in Figure 1. 


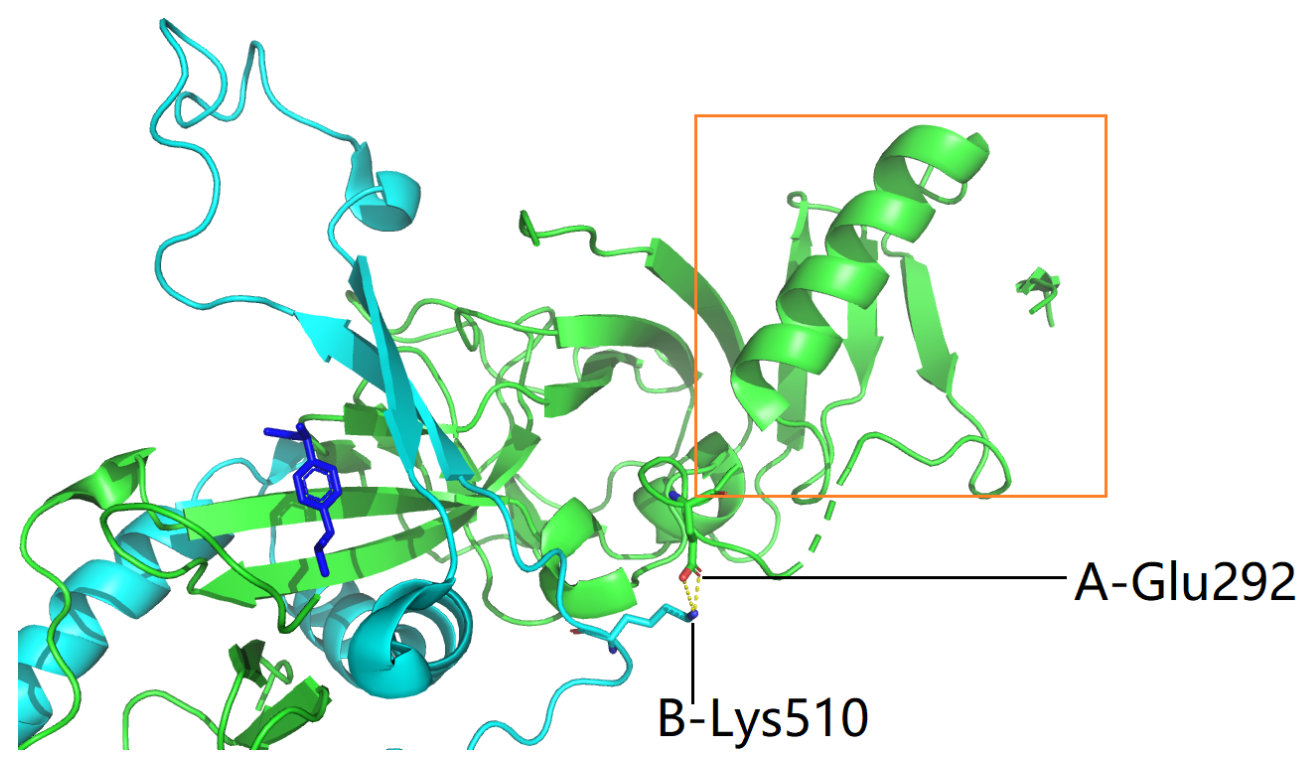

Figure 3. A hypothesis of two Achilles' heels of the Ebolavirus glycoprotein. In this figure, the first hypothesized Achilles' heel is shown as the two structurally identified interfacial salt bridges (two yellow dotted lines) between B_LYS_510 and A_GLU_292 (Table 3), which helps restrain the inter-chain conformational flexibility of Ebolavirus GP, and also contributes to local inter-chain structural rigidification [131] of Ebolavirus GP, as shown approximately in the region inside the box in orange. This figure is prepared using PyMol [130] with 5JQB.pdb (Table 1) as an input with other details the same as that described in Figure 1.

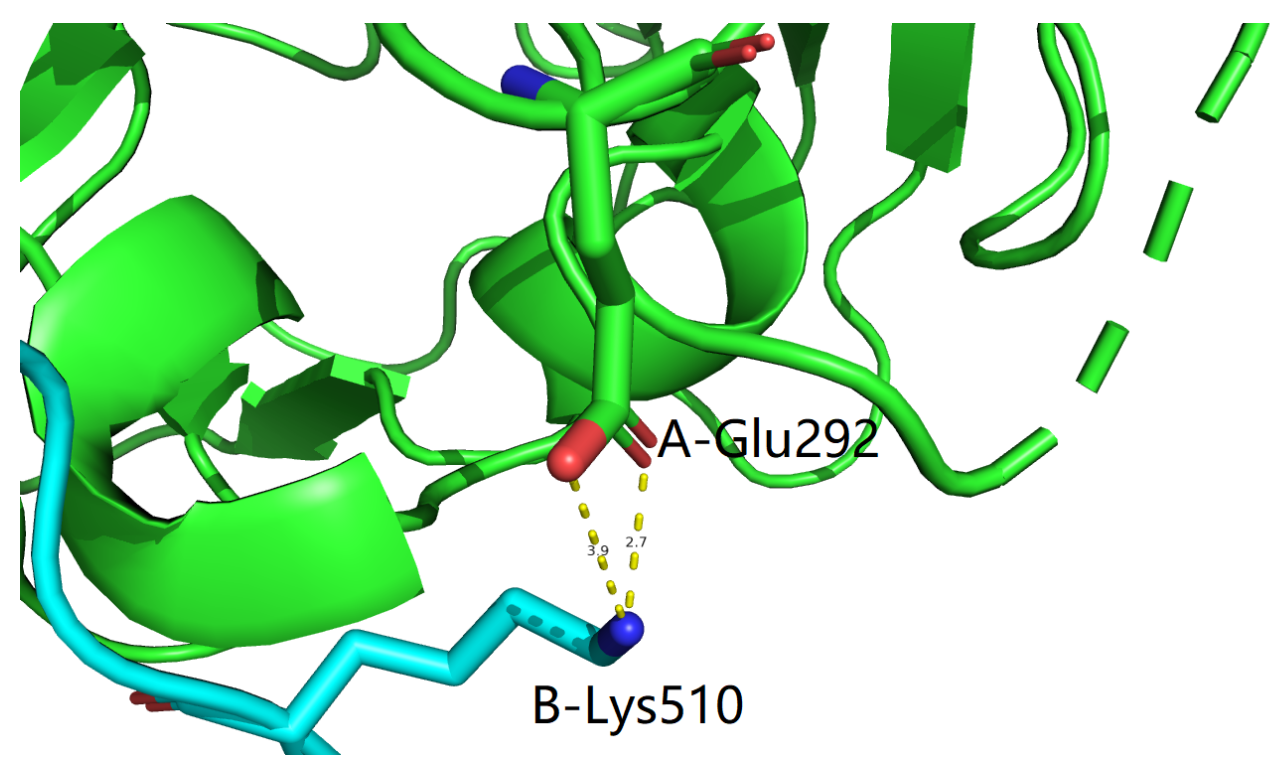

Figure 4. A hypothesis of two Achilles' heels of the Ebolavirus glycoprotein. In this figure, the first hypothesized Achilles' heel is shown as the two structurally identified interfacial salt bridges (two yellow dotted lines with two labels 3.9 and $2.7 \AA$ as their respective lengths) between B_LYS_510 and A_GLU_292 (Table 3), which helps restrain the inter-chain conformational flexibility of Ebolavirus GP, and also contributes to local inter-chain structural rigidification [131] of Ebolavirus GP. This figure is prepared using PyMol [130] with 5JQB.pdb (Table 1) as an input with other details the same as that described in Figure 1. 


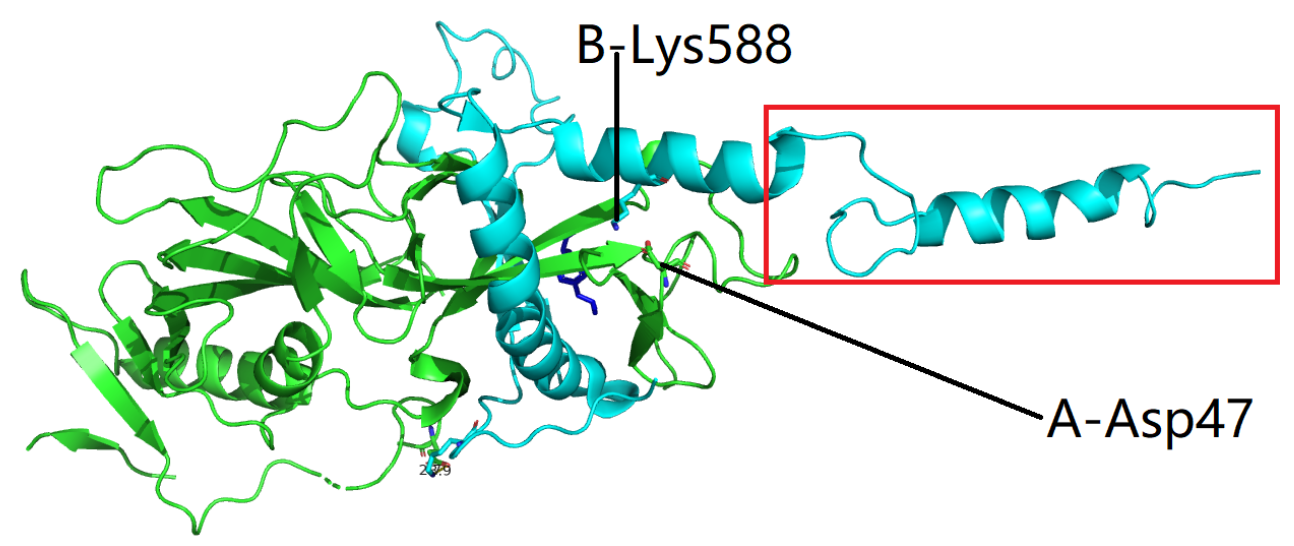

Figure 5. A hypothesis of two Achilles' heels of the Ebolavirus glycoprotein. In this figure, the second hypothesized Achilles' heel is shown as the two structurally identified interfacial salt bridges between B_LYS_588 and A_ASP_47 (Table 3), which helps restrain the inter-chain conformational flexibility of Ebolavirus GP, and also contributes to local inter-chain structural rigidification [131] of Ebolavirus GP, as shown approximately in the region inside the box in red. This figure is prepared using PyMol [130] with 5JQB.pdb (Table 1) as an input with other details the same as that described in Figure 1.

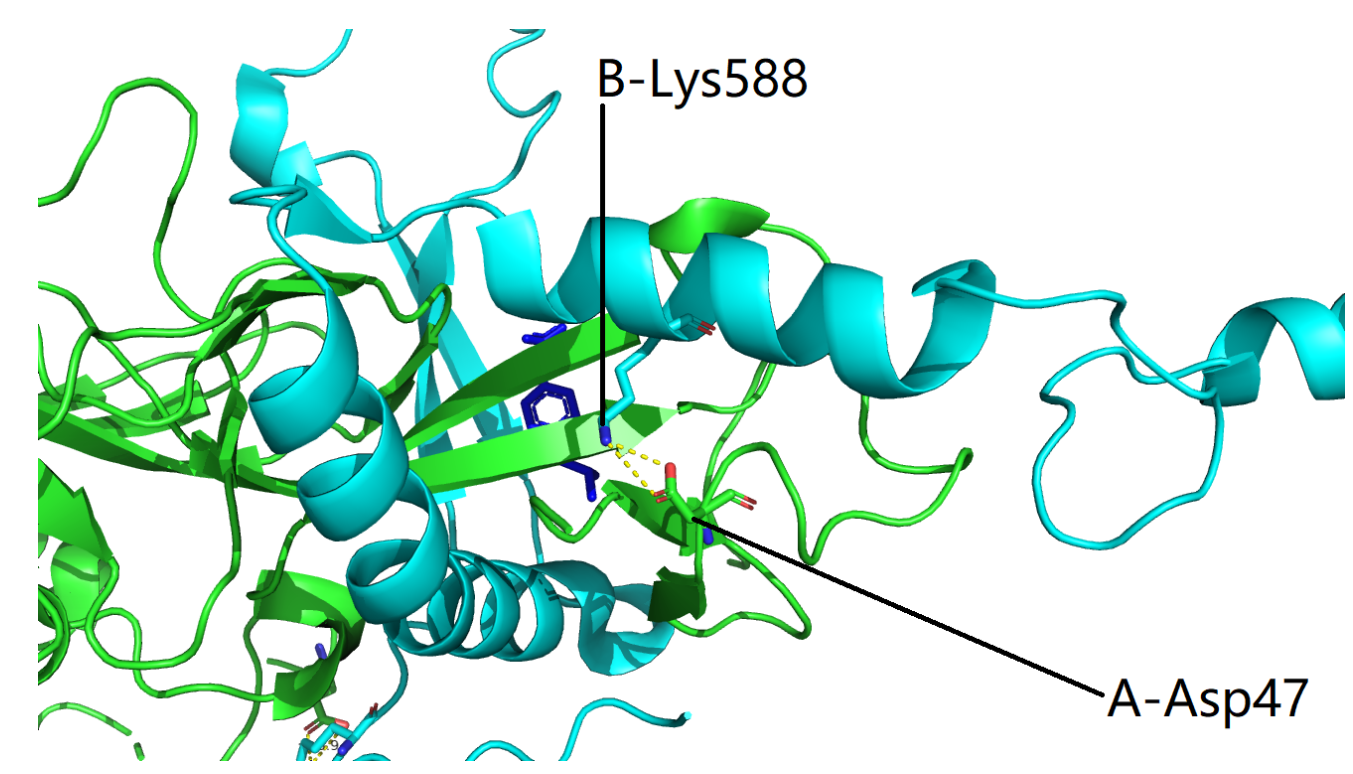

Figure 6. A hypothesis of two Achilles' heels of the Ebolavirus glycoprotein. In this figure, the second hypothesized Achilles' heel is shown as the two structurally identified interfacial salt bridges (two yellow dotted lines) between B_LYS_588 and A_ASP_47 (Table 3), which helps restrain the inter-chain conformational flexibility of Ebolavirus GP, and also contributes to local inter-chain structural rigidification [131] of Ebolavirus GP. This figure is prepared using PyMol [130] with 5JQB.pdb (Table 1) as an input with other details the same as that described in Figure 1. 


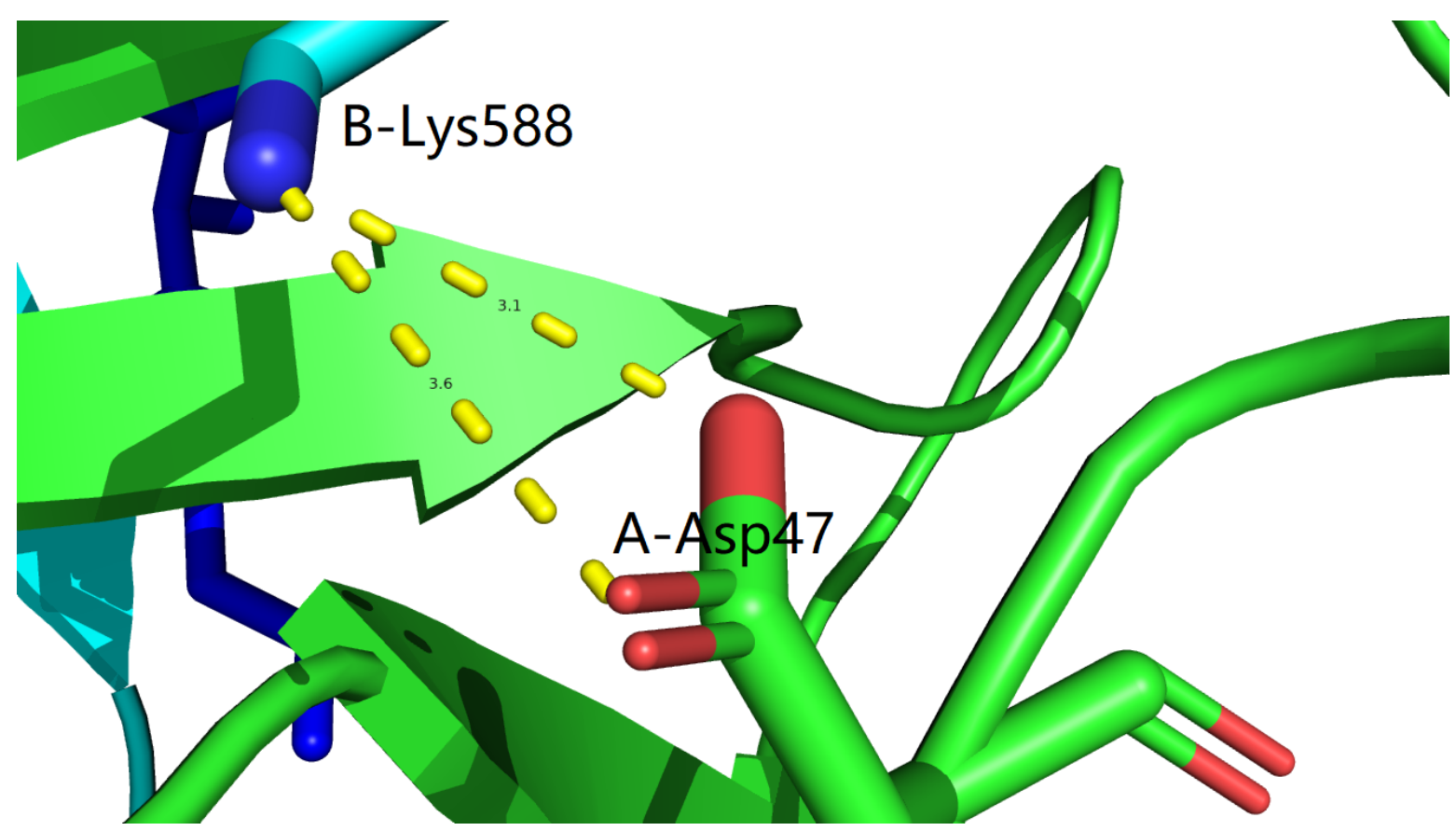

Figure 7. A hypothesis of two Achilles' heels of the Ebolavirus glycoprotein. In this figure, the second hypothesized Achilles' heel is shown as the two structurally identified interfacial salt bridges (two yellow dotted lines with two labels 3.1 and 3.6 $\AA$ as their respective lengths) between B_LYS_588 and A_ASP_47 (Table 3), which helps restrain the inter-chain conformational flexibility of Ebolavirus GP, and also contributes to local inter-chain structural rigidification [131] of Ebolavirus GP. This figure is prepared using PyMol [130] with 5JQB.pdb (Table 1) as an input with other details the same as that described in Figure 1.

Specifically, the two hypothesized Achilles' heels consist of two inter-chain salt bridges, i.e., B_LYS_510-A_GLU_292 (Figures 2, 3 and 4) and B_LYS_588-A_ASP_47 (Figures 5, 6 and 7), respectively. According to the structural electrostatic analysis [129], the apo unliganded Ebolavirus GP does not form any B_LYS_510-A_GLU_292 salt bridge, with the distances between charged atoms (two side chain carbonyl oxygens and one side chain nitrogen) being 4.7 and $6.6 \AA$, respectively. Nor does the apo unliganded Ebolavirus GP form any B_LYS_588-A_ASP_47 salt bridge, with the distances between charged atoms (two side chain carbonyl oxygens and one side chain nitrogen) being 13.4 and $11.6 \AA$, respectively.

To define this two Achilles' heel hypothesis, I take PDB ID (5JQB) as an example, which represents an experimentally determined complex structure of Ebolavirus GP and ibuprofen Table 1. In this hypothesis, the B_LYS_510-A_GLU_292 (Figures 2, 3 and 4) salt bridge allows chain B (via B_LYS_510) to restrain the inter-chain conformational flexibility of chain A (via A_GLU_292), contributing to local inter-chain structural rigidification [131], while the B_LYS_588-A_ASP_47 (Figures 5, 6 and 7) salt bridge allows chain A (via A_ASP_47) to restrain the inter-chain conformational flexibility of chain B (via B_LYS_588), contributing to local inter-chain structural rigidification [131], as shown in Figures 5, 6 and 7. This two Achilles' heel hypothesis highlights the functional importance of the conformational flexibility of the approximate structural region in the orange box (Figures 2 and 3) and the approximate structural region in the red box (Figure 5) in GP-mediated Ebolavirus cell entry and/or membrane-fusion. Quite similarly, according to a previously reported computational study [131], $\alpha_{2} \delta$-1-bound gabapentin establishes an electrostatic axis consisting of Q535 (Gln535)-R241 (Arg241)-GBP (gabapentin)-D452 (Asp452), which constitutes an energetically favourable contribution towards the structural stability of the $\alpha_{2} \delta-1-G B P$ complex and helps restrain the conformational flexibility and local structural rigidification of $\alpha_{2} \delta-1$, and that GBP-induced local conformational 
inflexibility and structural rigidification of $\alpha_{2} \delta-1$ is one key step in the pharmacological disruption of VGCC trafficking by GBP [132-142].

\section{Conclusion and Discussion}

For the first time, this article reports a comprehensive set of electrostatic features embedded inside currently (as of March 10, 2020) available Ebolavirus GP structures inside PDB [128] in both PDF format (supplementary file supplementary.pdf) and also $\mathrm{LT}_{\mathrm{E}} \mathrm{X}$ format, i.e., a series of machine-readable -importable and -analyzable tex files zipped in the supplementary file scan.zip. In supplementary file scan.zip, a simple python-based analysis tool and a $\mathrm{LT}_{\mathrm{E}} \mathrm{X}$-based editing tool [143] were included to extract and summarize the electrostatic features from experimentally determined structures, where a set of PDB files (representing experimentally determined protein structures) are to be plugged into a set of python scripts included in cmd.py. Afterwards, cmd.py is to be executed with a simple command (python cmd.py) on a Linux machine terminal to produce the final supplementary file supplementary.pdf, summarizing the structurally observed electrostatic features of the 36 Ebolavirus GP-related experimental structures as of March 10, 2020.

Moreover, this article puts forward a set of small molecule-induced perturbation of interfacial electrostatic interaction network within experimentally determined ebola GP structures, and hypothesizes that these small compounds inhibit viral cell entry and/or membrane-fusion by binding to the glycoprotein, inducing a minor conformational perturbation, leading to the establishment of two inter-chain salt bridges, i.e., B_LYS_510-A_GLU_292 (Figures 2, 3 and 4) and B_LYS_588-A_ASP_47 (Figures 5, 6 and 7), restraining the conformational flexibility of the approximate structural region in the orange box (Figures 2 and 3 ) and the approximate structural region in the red box (Figure 5) against GP-mediated Ebolavirus cell entry and/or membrane-fusion [14-16,115-118]. Along with previously reported details of the protein-inhibitor interactions of these complexes, this hypothesis may facilitate the design of more potent inhibitors of Ebolavirus cell entry [119-125,125,144-149] and the discovery of novel antiviral compounds [54,150-156] to prepare us for future outbreaks.

Author Contributions: Conceptualization, W.L.; methodology, W.L.; software, W.L.; validation, W.L.; formal analysis, W.L.; investigation, W.L.; resources, W.L.; data duration, W.L.; writing-original draft preparation, W.L.; writing-review and editing, W.L.; visualization, W.L.; supervision, W.L.; project administration, W.L.; funding acquisition, not applicable.

Funding: This research received no external funding.

Conflicts of Interest: The author declares no conflict of interest.

1. Malvy, D.; McElroy, A.K.; de Clerck, H.; Günther, S.; van Griensven, J. Ebola virus disease. The Lancet 2019, 393, 936-948.

2. Caron, A.; Bourgarel, M.; Cappelle, J.; Liégeois, F.; Nys, H.D.; Roger, F. Ebola Virus Maintenance: If Not (Only) Bats, What Else? Viruses 2018, 10, 549.

3. Venkatraman, N.; Silman, D.; Folegatti, P.M.; Hill, A.V. Vaccines against Ebola virus. Vaccine 2018, $36,5454-5459$.

4. Frieden, T.R. Still not ready for Ebola. Science 2018, 360, 1049-1049.

5. Lu, D.Y.; Wu, H.Y.; Yarla, N.S.; Lu, T.R.; Xu, B.; Jian-Ding. Ebola Therapeutic Study and Future Directions. Infectious Disorders - Drug Targets 2019, 19, 17-29.

6. Metzger, W.G.; Vivas-Martínez, S. Questionable efficacy of the rVSV-ZEBOV Ebola vaccine. The Lancet 2018, 391, 1021.

7. Gatherer, D. Ebola returns to its Congo Basin heartland. Journal of General Virology 2018, 99, 861-863.

8. Shepherd, A. Congolese fight against Ebola. BMJ 2018, p. k4814.

9. Hayden, E.C. Experimental drugs poised for use in Ebola outbreak. Nature 2018, 557, 475-476.

10. Delgado, R.; Simón, F. Transmission, Human Population, and Pathogenicity: the Ebola Case in Point. Microbiology Spectrum 2018, 6 .

11. Sheridan, C. Merck vaccine heads Ebola countermeasures. Nature Biotechnology 2018, 36, 563-565. 
12. Lucey, D.R. New treatments for Ebola virus disease. BMJ 2019, p. 15371.

13. Olgun, N.S. Viral Infections in Pregnancy: A Focus on Ebola Virus. Current Pharmaceutical Design 2018, 24, 993-998.

14. Zhao, D.; Han, X.; Zheng, X.; Wang, H.; Yang, Z.; Liu, D.; Han, K.; Liu, J.; Wang, X.; Yang, W.; Dong, Q.; Yang, S.; Xia, X.; Tang, L.; He, F. Correction: The Myeloid LSECtin Is a DAP12-Coupled Receptor That Is Crucial for Inflammatory Response Induced by Ebola Virus Glycoprotein. PLOS Pathogens 2016, 12, e1005542.

15. Zhao, Z.; Martin, C.; Fan, R.; Bourne, P.E.; Xie, L. Drug repurposing to target Ebola virus replication and virulence using structural systems pharmacology. BMC Bioinformatics 2016, 17.

16. Zhao, Y.; Ren, J.; Harlos, K.; Jones, D.M.; Zeltina, A.; Bowden, T.A.; Padilla-Parra, S.; Fry, E.E.; Stuart, D.I. Toremifene interacts with and destabilizes the Ebola virus glycoprotein. Nature 2016, 535, 169-172.

17. Cohen, J. Vaccine trial launched to stop Ebola. Science 2018, 360, 694-695.

18. Burki, T. Ebola virus vaccine receives prequalification. The Lancet 2019, 394, 1893.

19. Puyvelde, S.V.; Argimon, S. Sequencing in the time of Ebola. Nature Reviews Microbiology 2018, 17, 5-5.

20. Green, A. DR Congo: investigational research against Ebola virus. The Lancet 2018, 391, 2308-2309.

21. Butler, D. Speedy Ebola tests help contain Africa's latest outbreak. Nature 2018, 558, 172-172.

22. Salata, C.; Calistri, A.; Alvisi, G.; Celestino, M.; Parolin, C.; Palù, G. Ebola Virus Entry: From Molecular Characterization to Drug Discovery. Viruses 2019, 11, 274.

23. Tomori, O.; Durrheim, D.; Gostin, L.; Kavanagh, M.M. Ebola in North Kivu, DR Congo - is it an undeclared public health emergency of international concern (PHEIC)? Travel Medicine and Infectious Disease 2019, 29, 1-3.

24. Kyle, J.E.; Burnum-Johnson, K.E.; Wendler, J.P.; Eisfeld, A.J.; Halfmann, P.J.; Watanabe, T.; Sahr, F.; Smith, R.D.; Kawaoka, Y.; Waters, K.M.; Metz, T.O. Plasma lipidome reveals critical illness and recovery from human Ebola virus disease. Proceedings of the National Academy of Sciences 2019, 116, 3919-3928.

25. Duchene, S.; Bouckaert, R.; Duchene, D.A.; Stadler, T.; Drummond, A.J. Phylodynamic Model Adequacy Using Posterior Predictive Simulations. Systematic Biology 2018, 68, 358-364.

26. KOCK, R.; BEGOVOEVA, M.; ANSUMANA, R.; SULUKU, R. Searching for the source of Ebola: the elusive factors driving its spillover into humans during the West African outbreak of 2013-2016. Revue Scientifique et Technique de l'OIE 2019, 38, 113-122.

27. Mate, S.E.; Wiley, M.R.; Ladner, J.T.; Dokubo, E.K.; Fakoli, L.; Fallah, M.; Nyenswah, T.G.; DiClaro, J.W.; Deboer, J.T.; Williams, D.E.; Bolay, F.; Palacios, G. Cross-Border Transmission of Ebola Virus as the Cause of a Resurgent Outbreak in Liberia in April 2016. Clinical Infectious Diseases 2018, 67, 1147-1149.

28. Kelly, J.D.; Barrie, M.B.; Mesman, A.W.; Karku, S.; Quiwa, K.; Drasher, M.; Schlough, G.W.; Dierberg, K.; Koedoyoma, S.; Lindan, C.P.; Jones, J.H.; Chamie, G.; Worden, L.; Greenhouse, B.; Weiser, S.D.; Porco, T.C.; Rutherford, G.W.; Richardson, E.T. Anatomy of a Hotspot: Chain and Seroepidemiology of Ebola Virus Transmission, Sukudu, Sierra Leone, 2015-16. The Journal of Infectious Diseases 2018, 217, 1214-1221.

29. Haug, C.J. New England Journal of Medicine 2018, 378, 2353-2355.

30. Uekermann, F.; Simonsen, L.; Sneppen, K. Exploring the contribution of exposure heterogeneity to the cessation of the 2014 Ebola epidemic. PLOS ONE 2019, 14, e0210638.

31. Drelich, A.; Judy, B.; He, X.; Chang, Q.; Yu, S.; Li, X.; Lu, F.; Wakamiya, M.; Popov, V.; Zhou, J.; Ksiazek, T.; Gong, B. Exchange Protein Directly Activated by cAMP Modulates Ebola Virus Uptake into Vascular Endothelial Cells. Viruses 2018, 10, 563.

32. Lane, T.; Anantpadma, M.; Freundlich, J.S.; Davey, R.A.; Madrid, P.B.; Ekins, S. The Natural Product Eugenol Is an Inhibitor of the Ebola Virus In Vitro. Pharmaceutical Research 2019, 36.

33. dong Su, Q.; hua He, S.; Yi, Y.; Qiu, F.; xin Lu, X.; yuan Jia, Z.; ling Meng, Q.; ting Fan, X.; guang Tian, R.; Audet, J.; guo Qiu, X.; li Bi, S. Intranasal vaccination with ebola virus GP amino acids 258-601 protects mice against lethal challenge. Vaccine 2018, 36, 6053-6060.

34. Ploquin, A.; Zhou, Y.; Sullivan, N.J. Ebola Immunity: Gaining a Winning Position in Lightning Chess. The Journal of Immunology 2018, 201, 833-842.

35. Stein, D.R.; Sroga, P.; Warner, B.M.; Deschambault, Y.; Poliquin, G.; Safronetz, D. Evaluating Temperature Sensitivity of Vesicular Stomatitis Virus-Based Vaccines. Emerging Infectious Diseases 2019, 25, 1563-1566. 
36. Kapetshi, J.; Fausther-Bovendo, H.; Corbett, C.; Leung, A.; Ait-Ikhlef, K.; Nsio, J.; Aruna, A.; Ilunga, B.K.; Muyembe, J.J.; Formenty, P.; Kobinger, G.P. Contribution of Environment Sample-Based Detection to Ebola Outbreak Management. The Journal of Infectious Diseases 2018.

37. Yang, X.; Wang, X.; Song, Y.; Zhou, P.; Li, D.; Zhang, C.; Jin, X.; Huang, Z.; Zhou, D. Chimpanzee adenoviral vector prime-boost regimen elicits potent immune responses against Ebola virus in mice and rhesus macaques. Emerging Microbes E Infections 2019, 8, 1086-1097.

38. James, P.B.; Wardle, J.; Steel, A.; Adams, J. Utilisation of and Attitude towards Traditional and Complementary Medicine among Ebola Survivors in Sierra Leone. Medicina 2019, 55, 387.

39. Raftery, P.; Condell, O.; Wasunna, C.; Kpaka, J.; Zwizwai, R.; Nuha, M.; Fallah, M.; Freeman, M.; Harris, V.; Miller, M.; Baller, A.; Massaquoi, M.; Katawera, V.; Saindon, J.; Bemah, P.; Hamblion, E.; Castle, E.; Williams, D.; Gasasira, A.; Nyenswah, T. Establishing Ebola Virus Disease (EVD) diagnostics using GeneXpert technology at a mobile laboratory in Liberia: Impact on outbreak response, case management and laboratory systems strengthening. PLOS Neglected Tropical Diseases 2018, 12, e0006135.

40. Seesuay, W.; Jittavisutthikul, S.; Sae-lim, N.; Sookrung, N.; Sakolvaree, Y.; Chaicumpa, W. Human transbodies that interfere with the functions of Ebola virus VP35 protein in genome replication and transcription and innate immune antagonism. Emerging Microbes \& Infections 2018, 7, 1-15.

41. Tariq, A.; Roosa, K.; Mizumoto, K.; Chowell, G. Assessing reporting delays and the effective reproduction number: The Ebola epidemic in DRC, May 2018-January 2019. Epidemics 2019, 26, 128-133.

42. Spengler, J.R.; Welch, S.R.; Genzer, S.C.; Coleman-McCray, J.; Harmon, J.R.; Nichol, S.T.; Spiropoulou, C.F. Suboptimal Handling of Piccolo Samples or Reagent Discs for Consideration in Ebola Response. Emerging Infectious Diseases 2019, 25, 1238-1240.

43. O'Keefe, A.L.; Buss, B.F.; Koirala, S.; Gleason, M.X.; Mudgapalli, A.; Schwedhelm, S. REDCap for Biocontainment Worker Symptom Monitoring. Health Security 2019, 17, 3-10.

44. Turner, A.K.; Wages, R.K.; Nadeau, K.; Edison, L.; Prince, P.F.; Doss, E.R.; Drenzek, C.; O'Neal, P. The Infectious Disease Network (IDN): Development and Use for Evaluation of Potential Ebola Cases in Georgia. Disaster Medicine and Public Health Preparedness 2018, 12, 765-771.

45. Brett-Major, D.; Lawler, J. Catching Chances: The Movement to Be on the Ground and Research Ready before an Outbreak. Viruses 2018, 10, 439.

46. Si, L.; Meng, K.; Tian, Z.; Sun, J.; Li, H.; Zhang, Z.; Soloveva, V.; Li, H.; Fu, G.; Xia, Q.; Xiao, S.; Zhang, L.; Zhou, D. Triterpenoids manipulate a broad range of virus-host fusion via wrapping the HR2 domain prevalent in viral envelopes. Science Advances 2018, 4, eaau8408.

47. Emanuel, J.; Callison, J.; Dowd, K.A.; Pierson, T.C.; Feldmann, H.; Marzi, A. A VSV-based Zika virus vaccine protects mice from lethal challenge. Scientific Reports 2018, 8 .

48. Marston, H.D.; Paules, C.I.; Fauci, A.S. Monoclonal Antibodies for Emerging Infectious Diseases Borrowing from History. New England Journal of Medicine 2018, 378, 1469-1472.

49. Brekle, V.; Weiß, C.; Kolobaric, Z.; Schulz-Weidhaas, C.; Vogelmann, R. Ambulant praktizierende Ärzte in Deutschland unzureichend auf Ebolafieber vorbereitet. Das Gesundheitswesen 2018, 81, 839-845.

50. Maxmen, A. Experimental Ebola drugs face tough test in war zone. Nature 2018, 561, 14-14.

51. Levine, M.M. Monoclonal Antibody Therapy for Ebola Virus Disease. New England Journal of Medicine 2019, 381, 2365-2366.

52. Cnops, L.; Smet, B.D.; Mbala-Kingebeni, P.; van Griensven, J.; Ahuka-Mundeke, S.; Ariën, K.K. Where are the Ebola diagnostics from last time? Nature 2019, 565, 419-421.

53. Green, A. DR Congo Ebola virus treatment centres attacked. The Lancet 2019, 393, 1088.

54. Subissi, L. Can Ebola virus re-emerge from survivors' body fluids other than semen? The Lancet Infectious Diseases 2018, 18, 933-934.

55. Sofonea, M.T.; Aldakak, L.; Boullosa, L.F.V.V.; Alizon, S. Can Ebola virus evolve to be less virulent in humans? Journal of Evolutionary Biology 2018, 31, 382-392.

56. Devi, S. FRONTLINE: a new treatment facility for Ebola virus disease. The Lancet 2018, 392, 2428.

57. Younan, P.; Iampietro, M.; Bukreyev, A. Disabling of lymphocyte immune response by Ebola virus. PLOS Pathogens 2018, 14, e1006932.

58. Longini, I.M.; Røttingen, J.A.; Kieny, M.P.; Edmunds, W.J.; Henao-Restrepo, A.M. Questionable efficacy of the rVSV-ZEBOV Ebola vaccine - Authors' reply. The Lancet 2018, 391, 1021-1022.

59. Ersching, J.; Victora, G.D. Ebola from Bedside to Bench. Cell 2019, 177, 1370-1372. 
60. Ingelbeen, B.; Weggheleire, A.D.; Herp, M.V.; van Griensven, J. Symptom-Based Ebola Risk Score for Ebola Virus Disease, Conakry, Guinea. Emerging Infectious Diseases 2018, 24, 1162-1162.

61. Petersen, J.; Simons, H.; Patel, D. Amplification of perceived risk among users of a national travel health Web site during the 2013-2016 West African Ebola virus outbreak. American Journal of Infection Control 2018, $46,843-845$.

62. Sulaiman, W.A.; Mat, L.N.; Hoo, F.K.; Mohamed, M.H.; Lim, S.M. Is Ebola a sexually transmitted disease? Implication of Ebola RNA persistence in the semen. Journal of Infection and Public Health 2018, 11, 299.

63. Garry, R.F. Ebola Mysteries and Conundrums. The Journal of Infectious Diseases 2018, 219, 511-513.

64. Wang, Z.; Li, J.; Fu, Y.; Zhao, Z.; Zhang, C.; Li, N.; Li, J.; Cheng, H.; Jin, X.; Lu, B.; Guo, Z.; Qian, J.; Liu, L. A Rapid Screen for Host-Encoded miRNAs with Inhibitory Effects against Ebola Virus Using a Transcriptionand Replication-Competent Virus-Like Particle System. International Journal of Molecular Sciences 2018, 19, 1488.

65. Fa, J.E.; Nasi, R.; van Vliet, N. Viande de brousse, impacts anthropiques et santé humaine dans les forêts tropicales humides : le cas du virus Ebola. Santé Publique 2019, S1, 107.

66. Marzi, A.; Mire, C.E. Current Ebola Virus Vaccine Progress. BioDrugs 2019, 33, 9-14.

67. Agrawal, A.; Majdi, J.; Clouse, K.; Stantchev, T. Electron-Beam-Lithographed Nanostructures as Reference Materials for Label-Free Scattered-Light Biosensing of Single Filoviruses. Sensors 2018, 18, 1670.

68. Dhama, K.; Karthik, K.; Khandia, R.; Chakraborty, S.; Munjal, A.; Latheef, S.K.; Kumar, D.; Ramakrishnan, M.A.; Malik, Y.S.; Singh, R.; Malik, S.V.S.; Singh, R.K.; Chaicumpa, W. Advances in Designing and Developing Vaccines, Drugs, and Therapies to Counter Ebola Virus. Frontiers in Immunology 2018, 9.

69. Yuan, S.; Zhang, Z.W.; Li, Z.L. Bacteriophage M13 May Be Used for the Assessment of Viral Transfer during Doffing of Ebola-Level Personal Protective Equipment. Infection Control E Hospital Epidemiology 2018, 39, 762-763.

70. Saphire, E.O. A glimpse into immune responses evolving against Ebola virus. Nature Medicine 2019, $25,1470-1471$.

71. Mallow, M.; Gary, L.; Jeng, T.; Bongomin, B.; Aschkenasy, M.T.; Wallis, P.; Cranmer, H.H.; Debasu, E.; Levine, A.C. WASH activities at two Ebola treatment units in Sierra Leone. PLOS ONE 2018, 13, e0198235.

72. Veljkovic, V. Ibuprofen as a template molecule for drug design against Ebola virus. Frontiers in Bioscience 2018, 23, 947-953.

73. Campbell, F.; Didelot, X.; Fitzjohn, R.; Ferguson, N.; Cori, A.; Jombart, T. outbreaker2: a modular platform for outbreak reconstruction. BMC Bioinformatics 2018, 19.

74. McElroy, A.K.; Mühlberger, E.; Muñoz-Fontela, C. Immune barriers of Ebola virus infection. Current Opinion in Virology 2018, 28, 152-160.

75. Fallah, M.P.; Skrip, L.A. Ebola therapies: an unconventionally calculated risk. The Lancet 2019, 393, 850-852.

76. Nakkazi, E. Randomised controlled trial begins for Ebola therapeutics. The Lancet 2018, 392, 2338.

77. Mérens, A.; Bigaillon, C.; Delaune, D. Ebola virus disease: Biological and diagnostic evolution from 2014 to 2017. Médecine et Maladies Infectieuses 2018, 48, 83-94.

78. Bornholdt, Z.A.; Bradfute, S.B. Ebola virus vaccination and the longevity of total versus neutralising antibody response-is it enough? The Lancet Infectious Diseases 2018, 18, 699-700.

79. Moody, M.A. Strength through Organization: Classifying Antibody Activity against EBOV. Cell Host $\mathcal{E}$ Microbe 2018, 24, 185-186.

80. van Vuren, P.J.; Ladner, J.; Grobbelaar, A.; Wiley, M.; Lovett, S.; Allam, M.; Ismail, A.; le Roux, C.; Weyer, J.; Moolla, N.; Storm, N.; Kgaladi, J.; Sanchez-Lockhart, M.; Conteh, O.; Palacios, G.; Paweska, J. Phylodynamic Analysis of Ebola Virus Disease Transmission in Sierra Leone. Viruses 2019, 11, 71.

81. Holland, G.N.; Rimoin, A.W. The Ophthalmic Sequelae of Ebola. JAMA Ophthalmology 2018, 136, 693.

82. Damon, I.K.; Rollin, P.E.; Choi, M.J.; Arthur, R.R.; Redfield, R.R. New Tools in the Ebola Arsenal. New England Journal of Medicine 2018, 379, 1981-1983.

83. Zastrow, M. Why Japan imported Ebola ahead of the 2020 Olympics. Nature 2019, 574, 306-307.

84. Pini, A.; Zomahoun, D.; Duraffour, S.; Derrough, T.; Charles, M.; Quick, J.; Loman, N.; Cowley, L.; Leno, M.; Ouedraogo, N.; Thiam, O.; Hernández-Romieu, A.; Iko, A.; Keita, H.; Konate, D.; Soumah, A.A.; Bouchouar, E.; Ileka-Priouzeau, S.; Keita, S.; Diallo, B.; Cisse, F.; Jansa, J.; Carroll, M.; Günther, S.; Severi, E.; Formenty, P. Field investigation with real-time virus genetic characterisation support of a cluster of Ebola virus disease cases in Dubréka, Guinea, April to June 2015. Eurosurveillance 2018, 23. 
85. Best, S.M.; Feldmann, H. Tip Your Cap for Ebola Virus Neutralization. Immunity 2018, 49, 204-206.

86. Olliaro, P.L. Initiation and publication time-lags of treatment trials for Ebola virus disease. The Lancet Infectious Diseases 2018, 18, 28-29.

87. Chowell, G.; Tariq, A.; Kiskowski, M. Vaccination strategies to control Ebola epidemics in the context of variable household inaccessibility levels. PLOS Neglected Tropical Diseases 2019, 13, e0007814.

88. Wu, N.C.; Ward, A.B. Deception through Mimicry: A Cellular Antiviral Strategy. Cell 2018, 175, 1728-1729.

89. Alfson, K.; Avena, L.; Beadles, M.; Worwa, G.; Amen, M.; Patterson, J.; Carrion, R.; Griffiths, A. Intramuscular Exposure of Macaca fascicularis to Low Doses of Low Passage- or Cell Culture-Adapted Sudan Virus or Ebola Virus. Viruses 2018, 10, 642.

90. Gross, L.; Lhomme, E.; Pasin, C.; Richert, L.; Thiebaut, R. Ebola vaccine development: Systematic review of pre-clinical and clinical studies, and meta-analysis of determinants of antibody response variability after vaccination. International Journal of Infectious Diseases 2018, 74, 83-96.

91. Postigo-Hidalgo, I.; Fischer, C.; Moreira-Soto, A.; Tscheak, P.; Nagel, M.; Eickmann, M.; Drexler, J.F. Pre-emptive genomic surveillance of emerging ebolaviruses. Eurosurveillance 2020, 25.

92. Karan, L.S.; Makenov, M.T.; Korneev, M.G.; Sacko, N.; Boumbaly, S.; Yakovlev, S.A.; Kourouma, K.; Bayandin, R.B.; Gladysheva, A.V.; Shipovalov, A.V.; Yurganova, I.A.; Grigorieva, Y.E.; Fedorova, M.V.; Scherbakova, S.A.; Kutyrev, V.V.; Agafonov, A.P.; Maksyutov, R.A.; Shipulin, G.A.; Maleev, V.V.; Boiro, M.; Akimkin, V.G.; Popova, A.Y. Bombali Virus in Mops condylurus Bats, Guinea. Emerging Infectious Diseases 2019, 25.

93. Mali, S.; Chaudhari, H. Molecular modelling studies on adamantane-based Ebola virus GP-1 inhibitors using docking, pharmacophore and 3D-QSAR. SAR and QSAR in Environmental Research 2019, 30, 161-180.

94. Bart, S.M.; Cohen, C.; Dye, J.M.; Shorter, J.; Bates, P. Enhancement of Ebola virus infection by seminal amyloid fibrils. Proceedings of the National Academy of Sciences 2018, 115, 7410-7415.

95. Madelain, V.; Baize, S.; Jacquot, F.; Reynard, S.; Fizet, A.; Barron, S.; Solas, C.; Lacarelle, B.; Carbonnelle, C.; Mentré, F.; Raoul, H.; de Lamballerie, X.; Guedj, J. Ebola viral dynamics in nonhuman primates provides insights into virus immuno-pathogenesis and antiviral strategies. Nature Communications 2018, 9.

96. Cooper, T.K.; Huzella, L.; Johnson, J.C.; Rojas, O.; Yellayi, S.; Sun, M.G.; Bavari, S.; Bonilla, A.; Hart, R.; Jahrling, P.B.; Kuhn, J.H.; Zeng, X. Histology, immunohistochemistry, and in situ hybridization reveal overlooked Ebola virus target tissues in the Ebola virus disease guinea pig model. Scientific Reports 2018, 8.

97. Lee, N.; Shum, D.; König, A.; Kim, H.; Heo, J.; Min, S.; Lee, J.; Ko, Y.; Choi, I.; Lee, H.; Radu, C.; Hoenen, T.; Min, J.Y.; Windisch, M.P. High-throughput drug screening using the Ebola virus transcription- and replication-competent virus-like particle system. Antiviral Research 2018, 158, 226-237.

98. Loignon, C.; Nouvet, E.; Couturier, F.; Benhadj, L.; Adhikari, N.K.J.; Murthy, S.; Fowler, R.A.; Lamontagne, F. Barriers to supportive care during the Ebola virus disease outbreak in West Africa: Results of a qualitative study. PLOS ONE 2018, 13, e0201091.

99. Nanbo, A.; Kawaoka, Y. Molecular Mechanism of Externalization of Phosphatidylserine on the Surface of Ebola Virus Particles. DNA and Cell Biology 2019, 38, 115-120.

100. Eickmann, M.; Gravemann, U.; Handke, W.; Tolksdorf, F.; Reichenberg, S.; Müller, T.H.; Seltsam, A. Inactivation of Ebola virus and Middle East respiratory syndrome coronavirus in platelet concentrates and plasma by ultraviolet $C$ light and methylene blue plus visible light, respectively. Transfusion 2018, 58, 2202-2207.

101. Aruna, A.; Mbala, P.; Minikulu, L.; Mukadi, D.; Bulemfu, D.; Edidi, F.; Bulabula, J.; Tshapenda, G.; Nsio, J.; Kitenge, R.; Mbuyi, G.; Mwanzembe, C.; Kombe, J.; Lubula, L.; Shako, J.C.; Mossoko, M.; Mulangu, F.; Mutombo, A.; Sana, E.; Tutu, Y.; Kabange, L.; Makengo, J.; Tshibinkufua, F.; Ahuka-Mundeke, S.; Muyembe, J.J.; CDC, E.R.; Alarcon, W.; Bonwitt, J.; Bugli, D.; Bustamante, N.D.; Choi, M.; Dahl, B.A.; DeCock, K.; Dismer, A.; Doshi, R.; Dubray, C.; Fitter, D.; Ghiselli, M.; Hall, N.; Hamida, A.B.; McCollum, A.M.; Neatherlin, J.; Raghunathan, P.L.; Ravat, F.; Reynolds, M.G.; Rico, A.; Smith, N.; Soke, G.N.; Trudeau, A.T.; Victory, K.R.; and, M.C.W. Ebola Virus Disease Outbreak - Democratic Republic of the Congo, August 2018-November 2019. MMWR. Morbidity and Mortality Weekly Report 2019, 68, 1162-1165.

102. Richards, G.A.; Baker, T.; Amin, P. Ebola virus disease: Report from the task force on tropical diseases by the World Federation of Societies of Intensive and Critical Care Medicine. Journal of Critical Care 2018, 43, 352-355. 
103. Li, Y.; Wang, H.; Jin, X.R.; Li, X.; Pender, M.; Song, C.P.; Tang, S.L.; Cao, J.; Wu, H.; Wang, Y.G. Experiences and challenges in the health protection of medical teams in the Chinese Ebola treatment center, Liberia: a qualitative study. Infectious Diseases of Poverty 2018, 7.

104. Reusken, C.B.; Mögling, R.; Smit, P.W.; Grunow, R.; Ippolito, G.; Caro, A.D.; Koopmans, M. Status, quality and specific needs of Ebola virus diagnostic capacity and capability in laboratories of the two European preparedness laboratory networks EMERGE and EVD-LabNet. Eurosurveillance 2018, 23.

105. Baudel, H.; Nys, H.D.; Ngole, E.M.; Peeters, M.; Desclaux, A. Understanding Ebola virus and other zoonotic transmission risks through human-bat contacts: Exploratory study on knowledge, attitudes and practices in Southern Cameroon. Zoonoses and Public Health 2019, 66, 288-295.

106. Khan, S.; Muhammad.; Rauf, A.; Khan, A.; Rizwan, M.; Patel, S.; Khan, H.; Mahasneh, A.M.; Mubarak, M.S. Comprehensive Review on Ebola (EBOV) Virus: Future Prospects. Infectious Disorders - Drug Targets 2018, 18, 96-104.

107. Postnikova, E.; Cong, Y.; DeWald, L.E.; Dyall, J.; Yu, S.; Hart, B.J.; Zhou, H.; Gross, R.; Logue, J.; Cai, Y.; Deiuliis, N.; Michelotti, J.; Honko, A.N.; Bennett, R.S.; Holbrook, M.R.; Olinger, G.G.; Hensley, L.E.; Jahrling, P.B. Testing therapeutics in cell-based assays: Factors that influence the apparent potency of drugs. PLOS ONE 2018, 13, e0194880.

108. Fénéant, L.; de Wijs, K.M.S.; Nelson, E.A.; White, J.M. An exploration of conditions proposed to trigger the Ebola virus glycoprotein for fusion. PLOS ONE 2019, 14, e0219312.

109. Shrivastava-Ranjan, P.; Flint, M.; Bergeron, É.; McElroy, A.K.; Chatterjee, P.; Albariño, C.G.; Nichol, S.T.; Spiropoulou, C.F. Statins Suppress Ebola Virus Infectivity by Interfering with Glycoprotein Processing. mBio 2018, 9.

110. Weidmann, M.; Faye, O.; Faye, O.; Wahed, A.A.E.; Patel, P.; Batejat, C.; Manugerra, J.C.; Adjami, A.; Niedrig, M.; Hufert, F.T.; Sall, A.A. Development of Mobile Laboratory for Viral Hemorrhagic Fever Detection in Africa. The Journal of Infectious Diseases 2018, 218, 1622-1630.

111. Wu, T.S.J.; Kagoli, M.; Kaasbøll, J.J.; Bjune, G.A. Integrated Disease Surveillance and Response (IDSR) in Malawi: Implementation gaps and challenges for timely alert. PLOS ONE 2018, 13, e0200858.

112. Pavadai, E.; Gerstman, B.S.; Chapagain, P.P. A cylindrical assembly model and dynamics of the Ebola virus VP40 structural matrix. Scientific Reports 2018, 8.

113. Nys, H.M.D.; Kingebeni, P.M.; Keita, A.K.; Butel, C.; Thaurignac, G.; Villabona-Arenas, C.J.; Lemarcis, T.; Geraerts, M.; Vidal, N.; Esteban, A.; Bourgarel, M.; Roger, F.; Leendertz, F.; Diallo, R.; Ndimbo-Kumugo, S.P.; Nsio-Mbeta, J.; Tagg, N.; Koivogui, L.; Toure, A.; Delaporte, E.; Ahuka-Mundeke, S.; Tamfum, J.J.M.; Mpoudi-Ngole, E.; Ayouba, A.; Peeters, M. Survey of Ebola Viruses in Frugivorous and Insectivorous Bats in Guinea, Cameroon, and the Democratic Republic of the Congo, 2015-2017. Emerging Infectious Diseases 2018, 24, 2228-2240.

114. Worden, L.; Wannier, R.; Hoff, N.A.; Musene, K.; Selo, B.; Mossoko, M.; Okitolonda-Wemakoy, E.; Tamfum, J.J.M.; Rutherford, G.W.; Lietman, T.M.; Rimoin, A.W.; Porco, T.C.; Kelly, J.D. Projections of epidemic transmission and estimation of vaccination impact during an ongoing Ebola virus disease outbreak in Northeastern Democratic Republic of Congo, as of Feb. 25, 2019. PLOS Neglected Tropical Diseases 2019, 13, e0007512.

115. Ren, J.; Zhao, Y.; Fry, E.E.; Stuart, D.I. Target Identification and Mode of Action of Four Chemically Divergent Drugs against Ebolavirus Infection. Journal of Medicinal Chemistry 2018, 61, 724-733.

116. Shaikh, F.; Zhao, Y.; Alvarez, L.; Iliopoulou, M.; Lohans, C.; Schofield, C.J.; Padilla-Parra, S.; Siu, S.W.I.; Fry, E.E.; Ren, J.; Stuart, D.I. Structure-Based in Silico Screening Identifies a Potent Ebolavirus Inhibitor from a Traditional Chinese Medicine Library. Journal of Medicinal Chemistry 2019, 62, 2928-2937.

117. Zhao, Y.; Ren, J.; Fry, E.E.; Xiao, J.; Townsend, A.R.; Stuart, D.I. Structures of Ebola Virus Glycoprotein Complexes with Tricyclic Antidepressant and Antipsychotic Drugs. Journal of Medicinal Chemistry 2018, 61, 4938-4945.

118. Boon, S.D.; Marston, B.J.; Nyenswah, T.G.; Jambai, A.; Barry, M.; Keita, S.; Durski, K.; Senesie, S.S.; Perkins, D.; Shah, A.; Green, H.H.; Hamblion, E.L.; Lamunu, M.; Gasasira, A.; Mahmoud, N.O.; Djingarey, M.H.; Morgan, O.; Crozier, I.; Dye, C. Ebola Virus Infection Associated with Transmission from Survivors. Emerging Infectious Diseases 2019, 25, 249-255.

119. Holbrook, M.R. Will a Single-Cycle Adenovirus Vaccine Be Effective Against Ebola Virus? The Journal of Infectious Diseases 2018, 218, 1858-1860. 
120. Yamayoshi, S.; Kawaoka, Y. Host protein mimics viral protein to hinder infection by Ebola virus. Nature 2019, 566, 190-191.

121. Racine, T. Following the roadmap toward an effective Ebola virus treatment. The Lancet Infectious Diseases 2018, 18, 820-822.

122. Lamontagne, F.; Clément, C.; Kojan, R.; Godin, M.; Kabuni, P.; Fowler, R.A. The evolution of supportive care for Ebola virus disease. The Lancet 2019, 393, 620-621.

123. Schafer, A.; Cheng, H.; Lee, C.; Du, R.; Han, J.; Perez, J.; Peet, N.; Manicassamy, B.; Rong, L. Development of Potential Small Molecule Therapeutics for Treatment of Ebola Virus Disease. Current Medicinal Chemistry 2019, 25, 5177-5190.

124. Piot, P.; Spencer, J. From 1976 to 2018: reflections on early investigations into the Ebola virus. Transactions of The Royal Society of Tropical Medicine and Hygiene 2018, 112, 527-528.

125. Maxmen, A. Science under fire: Ebola researchers fight to test drugs and vaccines in a war zone. Nature 2019, 572, 16-17.

126. Steven, A.C.; Baumeister, W. The future is hybrid. Journal of Structural Biology 2008, 163, 186-195.

127. Li, W.; Shi, G. How Cav1.2-bound verapamil blocks $\mathrm{Ca}^{2+}$ influx into cardiomyocyte: Atomic level views. Pharmacological Research 2019, 139, 153-157. doi:10.1016/j.phrs.2018.11.017.

128. Berman, H.; Henrick, K.; Nakamura, H. Announcing the worldwide Protein Data Bank. Nature Structural E Molecular Biologydec, 10, 980-980.

129. Li, W. How do SMA-linked mutations of SMN1 lead to structural/functional deficiency of the SMA protein? PLOS ONE 2017, 12, e0178519.

130. DeLano, W.L. Pymol: An open-source molecular graphics tool. CCP4 Newsletter On Protein Crystallography 2002, 40, 82-92.

131. Li, W. Calcium Channel Trafficking Blocker Gabapentin Bound to the $\alpha 2 \delta-1$ Subunit of Voltage-Gated Calcium Channel: A Computational Structural Investigation 2020.

132. Hendrich, J.; Minh, A.T.V.; Heblich, F.; Nieto-Rostro, M.; Watschinger, K.; Striessnig, J.; Wratten, J.; Davies, A.; Dolphin, A.C. Pharmacological disruption of calcium channel trafficking by the $\alpha 2 \delta$ ligand gabapentin. Proceedings of the National Academy of Sciences 2008, 105, 3628-3633.

133. Dolphin, A.C. Calcium channel auxiliary $\alpha 2 \delta$ and $\beta$ subunits: trafficking and one step beyond. Nature Reviews Neuroscience 2012, 13, 542-555.

134. SILLS, G. The mechanisms of action of gabapentin and pregabalin. Current Opinion in Pharmacology 2006, $6,108-113$.

135. Belliotti, T.R.; Capiris, T.; Ekhato, I.V.; Kinsora, J.J.; Field, M.J.; Heffner, T.G.; Meltzer, L.T.; Schwarz, J.B.; Taylor, C.P.; Thorpe, A.J.; Vartanian, M.G.; Wise, L.D.; Zhi-Su, T.; Weber, M.L.; Wustrow, D.J. Structure-Activity Relationships of Pregabalin and Analogues That Target the $\alpha 2-\delta$ Protein. Journal of Medicinal Chemistry 2005, 48, 2294-2307.

136. Taylor, C.P.; Gee, N.S.; Su, T.Z.; Kocsis, J.D.; Welty, D.F.; Brown, J.P.; Dooley, D.J.; Boden, P.; Singh, L. A summary of mechanistic hypotheses of gabapentin pharmacology. Epilepsy Research 1998, 29, 233-249.

137. Evoy, K.E.; Morrison, M.D.; Saklad, S.R. Abuse and Misuse of Pregabalin and Gabapentin. Drugs 2017, 77, 403-426.

138. dan Li, X.; Han, C.; li Yu, W. Is gabapentin effective and safe in open hysterectomy? A PRISMA compliant meta-analysis of randomized controlled trials. Journal of Clinical Anesthesia 2017, 41, 76-83.

139. Rai, A.S.; Khan, J.S.; Dhaliwal, J.; Busse, J.W.; Choi, S.; Devereaux, P.; Clarke, H. Preoperative pregabalin or gabapentin for acute and chronic postoperative pain among patients undergoing breast cancer surgery: A systematic review and meta-analysis of randomized controlled trials. Journal of Plastic, Reconstructive $\mathcal{E}$ Aesthetic Surgery 2017, 70, 1317-1328.

140. Bonnet, U.; Scherbaum, N. How addictive are gabapentin and pregabalin? A systematic review. European Neuropsychopharmacology 2017, 27, 1185-1215.

141. Senderovich, H.; Jeyapragasan, G. Is there a role for combined use of gabapentin and pregabalin in pain control? Too good to be true? Current Medical Research and Opinion 2017, 34, 677-682.

142. Saeki, K.; ichi Yasuda, S.; Kato, M.; Kano, M.; Domon, Y.; Arakawa, N.; Kitano, Y. Analgesic effects of mirogabalin, a novel ligand for $\alpha 2 \delta$ subunit of voltage-gated calcium channels, in experimental animal models of fibromyalgia. Naunyn-Schmiedeberg's Archives of Pharmacology 2019, 392, 723-728. 
143. Li, W. Extracting the Interfacial Electrostatic Features from Experimentally Determined Antigen and/or Antibody-Related Structures inside Protein Data Bank for Machine Learning-Based Antibody Design 2020.

144. Thompson, R.N.; Hart, W.S. Effect of Confusing Symptoms and Infectiousness on Forecasting and Control of Ebola Outbreaks. Clinical Infectious Diseases 2018, 67, 1472-1474.

145. Lachâtre, M.; Méchain, M.; Etienne, M.; Gautret, P.; Matheron, S.; Nahon, M.; Coignard-Biehler, H.; Malvy, D.; Duval, X.; Tattevin, P. No evidence for major adverse events related to suspicion of Ebola in France, 2014-2015. Clinical Microbiology and Infection 2018, 24, 310-311.

146. Dellicour, S.; Baele, G.; Dudas, G.; Faria, N.R.; Pybus, O.G.; Suchard, M.A.; Rambaut, A.; Lemey, P. Phylodynamic assessment of intervention strategies for the West African Ebola virus outbreak. Nature Communications 2018, 9.

147. Mbala-Kingebeni, P.; Villabona-Arenas, C.J.; Vidal, N.; Likofata, J.; Nsio-Mbeta, J.; Makiala-Mandanda, S.; Mukadi, D.; Mukadi, P.; Kumakamba, C.; Djokolo, B.; Ayouba, A.; Delaporte, E.; Peeters, M.; Tamfum, J.J.M.; Ahuka-Mundeke, S. Rapid Confirmation of the Zaire Ebola Virus in the Outbreak of the Equateur Province in the Democratic Republic of Congo: Implications for Public Health Interventions. Clinical Infectious Diseases 2018, 68, 330-333.

148. Forbes, K.M.; Webala, P.W.; Jääskeläinen, A.J.; Abdurahman, S.; Ogola, J.; Masika, M.M.; Kivistö, I.; Alburkat, H.; Plyusnin, I.; Levanov, L.; Korhonen, E.M.; Huhtamo, E.; Mwaengo, D.; Smura, T.; Mirazimi, A.; Anzala, O.; Vapalahti, O.; Sironen, T. Bombali Virus in Mops condylurus Bat, Kenya. Emerging Infectious Diseases 2019, 25.

149. Kunkel, A.; Keita, M.; Diallo, B.; le Polain de Waroux, O.; Subissi, L.; Wague, B.; Molala, R.; Lonfandjo, P.; Bokete, S.B.; Perea, W.; Djingarey, M.H. Assessment of a health facility based active case finding system for Ebola virus disease in Mbandaka, Democratic Republic of the Congo, June-July 2018. BMC Infectious Diseases 2019, 19.

150. Häfner, S. Guns N/ viruses. Microbes and Infection 2019, 21, 125-128.

151. Cantoni, D.; Rossman, J.S. Ebolaviruses: New roles for old proteins. PLOS Neglected Tropical Diseases 2018, 12, e0006349.

152. Dedkov, V.G.; Magassouba, N.; Safonova, M.V.; Bodnev, S.A.; Pyankov, O.V.; Camara, J.; Sylla, B.; Agafonov, A.P.; Maleev, V.V.; Shipulin, G.A. Sensitive Multiplex Real-time RT-qPCR Assay for the Detection of Filoviruses. Health Security 2018, 16, 14-21.

153. Crozier, I. Mapping a Filoviral Serologic Footprint in the Democratic Republic of the Congo: Who Goes There? The Journal of Infectious Diseases 2018, 217, 513-515.

154. Whitmer, S.L.; Ladner, J.T.; Wiley, M.R.; Patel, K.; Dudas, G.; Rambaut, A.; Sahr, F.; Prieto, K.; Shepard, S.S.; Carmody, E.; Knust, B.; Naidoo, D.; Deen, G.; Formenty, P.; Nichol, S.T.; Palacios, G.; Ströher, U. Active Ebola Virus Replication and Heterogeneous Evolutionary Rates in EVD Survivors. Cell Reports 2018, 22, 1159-1168.

155. Palyi, B.; Magyar, N.; Henczko, J.; Szalai, B.; Farkas, A.; Strecker, T.; Takacs, M.; Kis, Z. Determining the effect of different environmental conditions on Ebola virus viability in clinically relevant specimens. Emerging Microbes \& Infections 2018, 7, 1-7.

156. Yamayoshi, S.; Kawaoka, Y. Uncovering the Anti-Ebola Repertome. Cell Host E Microbe 2020, $27,163-165$. 